\title{
К ВОПРОСУ ОБ ИСПОЛЬЗОВАНИИ СТАТИСТИЧЕСКИХ МЕТОДОВ ДЛЯ ПОИСКА КОЛЛОКАЦИЙ И КОЛЛИГАЦИЙ В ДРЕВНЕЙШИХ СЛАВЯНСКИХ ТЕКСТАХ (НА МАТЕРИАЛЕ ГЛАГОЛИЧЕСКИХ РУКОПИСЕЙ КОРПУСА »МАНУСКРИПТ «)
}

\footnotetext{
Работа посвящена вопросам методики поиска цельных сочетаний в коллекции глаголических текстов исторического корпуса Манускрипт: славянское письменное насле$\partial u e$ (manuscripts.ru) и оценки их устойчивости. Демонстрируются возможности модуля n-грамм, позволяющие извлекать сочетания, имеющие разное количество компонентов, различную частотность, состоящие из текстовых форм или из лемм. Анализируются биграммы и триграммы, извлеченные с помощью статистической меры Mutual Information и встречающиеся одновременно в нескольких рукописях коллекции.

Особое внимание обращается на п-граммы, имеющие высокие статистические значения меры. В соответствии с особенностями меры наибольшие значения имеют редкие в коллекции сочетания. Анализ таких биграмм на основе словоформ позволил выявить устойчивые грамматические конструкции - коллигации. Показывается, что триграммы, состоящие из текстовых форм, являются не только грамматически, но и семантически цельными - коллокациями. Разнообразны биграммы с компонентами-леммами - предложно-падежные сочетания, именные сочетания с зависимыми притяжательными местоимениями и иные атрибутивные конструкции, глагольные конструкции с зависимыми существительными и другие. Анализ этих групп позволил выявить как коллигации, так и коллокации. Наиболее результативным стало извлечение триграмм на основе лемм - подавляющая часть первых нескольких десятков сочетаний, имеющих максимальное значение в соответствии со статистической мерой MI, представляет собой грамматически и семантически цельные конструкции или их части.
} 
Делается вывод об эффективности использования статистических методов для извлечения коллокаций и коллигаций из корпусов, содержащих средневековые славянские рукописи. Указывается, что для комплексного решения поставленной задачи должны быть использованы различные виды n-грамм - двукомпонентные и трехкомпонентные, на основе текстовых форм и лемм, со свободным и фиксированным порядком следования компонентов. Наличие повторяющихся в различных рукописях грамматически и семантически цельных сочетаний позволяет сделать вывод о надтекстовой природе таких сочетаний.

Ключевые слова: текстовый корпус »Манускрипт«, manuscripts.ru, глаголическая рукопись, лингвистическая статистика, модуль n-грамм, коллокация, коллигация

\section{1. ВВЕДЕНИЕ: КОРПУС ТЕКСТОВ. СТАТИСТИЧЕСКИЕ МЕТОДЫ. ГЛАГОЛИЧЕСКИЕ РУКОПИСИ}

Корпусные технологии предоставили лингвистам новые возможности работы с текстами, главная из которых - наблюдение за функционированием лингвистических единиц (их активностью, сочетаемостью, вариативностью) в очень больших объемах текстов с учетом жанровых, временных, гендерных и иных характеристик произведений. Появление машиночитаемых размеченных коллекций средневековых письменных памятников, снабженных средствами поиска и упорядочения лингвистических данных, дает специалистам по истории славянских языков новый инструментарий как для нахождения материала для анализа традиционными методами, так и для постановки и решения задач, данными для которых являются количественные и дистрибутивные характеристики единиц текста.

Информация о сочетаемости является одной из важнейших характеристик текстовых форм и слов. В разной степени грамматически и семантически цельные сочетания являются объектом теоретических исследований морфологов, синтаксистов, фразеологов, лексикологов, семасиологов, а также материалом для создания систем автоматического перевода, распознавания речи, алгоритмов стилеметрии, процедур извлечения информации и разработок в области искусственного интеллекта.

Достаточно продуктивным способом нахождения устойчивых грамматических и/или семантических комплексов и сочетаний, претендующих на такой статус - коллокаций и коллигаций - считаются статистические методы оценки степени связанности компонентов текста. ${ }^{1}$ Оценка

1 О понятиях коллокация и коллигация и о некоторых статистических методах их выделения см., например: HOHLOVA 2008; KOČETKOVA 2018; ONAL 2017; PECINA; 
осуществляется на основе данных о количестве некоторого сочетания, а также каждого из его компонентов в текстовом корпусе. Отклонение от средних, ожидаемых частот в сторону бо́льших величин является основанием считать, что хотя бы один из компонентов имеет ограниченную сочетаемость, а сочетание в целом является несвободным. Подобный подход позволяет выявить, с одной стороны, наиболее частотные сочетания - синтаксические конструкции, клише, терминологические сочетания, характеризующие документ, коллекцию, подкорпус в целом, а с другой - редкие, единичные устойчивые конструкции с ограниченной сочетаемостью компонентов - имена собственные, термины, идиомы, характеризующие тему текстов (HOHLOVA 2008: 347-348).

Появления первых машиночитаемых коллекций средневековых славянских письменных памятников создали условия для экспериментов по применению корпусных методов к новому материалу (BARANOV 2015).

2. ИСТОРИЧЕСКИЙ КОРПУС И СТАТИСТИКА: ЦЕЛЬ, ЛИНГВИСТИЧЕСКИЕ ДАННЫЕ, МЕТОДЫ, ИНСТРУМЕНТАРИЙ

\section{1. Цель работы}

Работа является продолжением начатых автором опытов по выявлению в глаголических текстах XI века устойчивых сочетаний. В статье содержится изложение результатов экспериментов по поиску повторяющихся в нескольких списках коллокаций и коллигаций и установлению степени их устойчивости.

\section{2. Лингвистические данные}

Материалом для анализа послужила коллекция глаголических рукописей портала »Манускрипть: славянское письменное наследие« (manuscripts.ru), включающая транскрипции 3 кодексов и 5 фрагментов, а именно: 1. Ассеманиево Евангелие, Slav. 3 Glag., X/ХІ вв. (ЕвАс); 2. Псалтырь Димитрия Синайского, Cod. Sin. slav. 3/N, третья четверть XI в. (ПсДС); 3. Литургиарий, Cod. Sin. slav. 5/N, вторая четверть XI в. (ЛитС);

SCHLESINGER 2006; VLAVACKAÂ 2011; ZHANG; IRIA; BREWSTER; CIRAVEGNA 2008. 
4. Литургиарий, фрагмент, вторая четверть ХІ в. (ЛитСФр); 5. Медицинские листки, Cod. Sin. slav. 3/N, последняя четверть ХІ в. (МедЛ); 6. Muнея синайская, Cod. Sin. slav. 4/N, последняя четверть XI в. (МинC); 7. Киевские листки, отрывок, X/XI в. и XII в. (КЛ) и 8. Часослов, фрагмент, первая четверть ХІ в. (Час) - (см. Источники).

Объем коллекции -89172 формы. $^{2}$ Количество лемматизированных текстовых прецедентов - 55220, количество лемм - 3024 .

Материал этой коллекции уже был объектом рассмотрения в статье (BARANOV 2017), в которой проанализированы данные 3-х кодексов и 4-х фрагментов. ${ }^{3}$ В работе показаны возможности модуля n-грамм корпуса »Манускрипт« (URL: http://manuscripts.ru/mns/cred_ngr.stat) и описано несколько экспериментов, которые позволили выявить многокомпонентные повторяющиеся чтения и формулы и двукомпонентные семантически и грамматически устойчивые сочетания. Последние найдены с помощью статистических мер Mutual information, T-Score и Dice. В частности, сделан вывод, что набор коллокаций индивидуален для каждого кодекса. И только в нескольких случаях отмечено использование пятикомпонентных и четырехкомпонентных сочетаний одновременно в нескольких рукописях. ${ }^{4}$

Анализ трехкомпонентных и двухкомпонентных устойчивых конструкций, использующихся в нескольких рукописях коллекции, не был осуществлен. Но именно такие сочетания, характеризующие не один, а несколько разножанровых текстов, могут рассматриваться как существенная характеристика подкорпуса в целом.

2 Объем рукописей и отрывков: ЕвАс - 43 287; ПсДС - 30 659; ЛитС - 12 474; КЛ - 1228; МинС - 485; МедЛ - 279; Час - 218; ЛитСФр - 542.

3 В коллекции отсутствовал фрагмент Литургиария (Санкт-Петербург, БРАН 24.4.8 \& РНБ, Глаг. 2), втор. четв. ХІ в., 3 л.

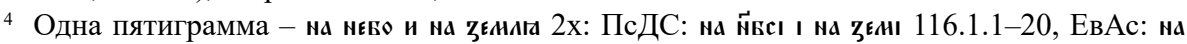
нБ̆сІ й на зємІ 73.2.2-3 (все примеры даются в упрощенной записи); 29 четырехграмм (в ряде случаев - части более развернутых конструкций) с разной структурой и разной степенью грамматической и семантической цельности: парные формулы - [въ инА]

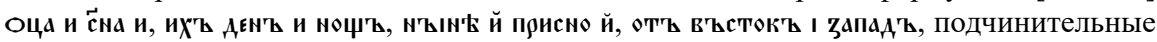
конструкции, в том числе с предложно-падежными компонентами, - въ домү о̆ца ноєго,

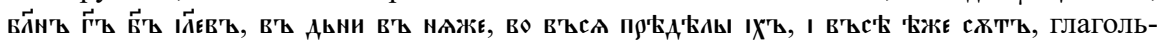

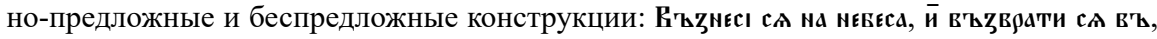

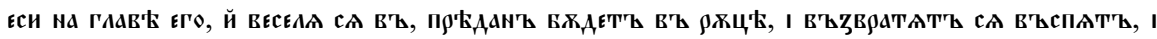

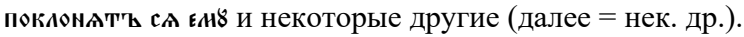




\section{3. Инструменты и методика}

Выборки для анализа были подготовлены с помощью модуля n-грамм корпуса (BARANOV 2014; BARANOV 2016.a; BARANOV 2016.b). Параметры n-грамм задавались с помощью полей: »Компонент - количество компонентов n-граммы; »Тип компонентов « - тип лингвистической единицы (словоформа или лемма); »Границы конструкций« - учет или не учет разделителей контекста; »Следование« - фиксированный или свободный порядок компонентов; »Мера« - статистический метод оценки сочетания.

В работе для нахождения характерных для коллекции устойчивых сочетаний использована статистическая мера MI - Mutual information (»взаимная информация«). ${ }^{5}$ Как известно, она присваивает наибольшие значения уникальным сочетаниям. Недостатком меры МІ является завышение значения редких сочетаний, содержащих единично встречающиеся компоненты, что корректируется, в частности, установлением порога частотности п-грамм (ÂGUNOVA; PIVOVAROVA 2010; ÂGUNOVA; PIVOVAROVA 2013; LUKAŠEVIČ; LOGAČEV 2010; ZALESSKAÂ 2014: 284; ZAHAROV; HOHLOVA 2014: 291; KOČETKOVA).

\section{3. ОБСУЖДЕНИЕ: N-ГРАММЫ. КОЛЛОКАЦИИ. КОЛЛИГАЦИИ}

\section{1. Биграммы. Словоформы}

Параметры n-грамм: тип компонентов - словоформы, количество компонентов -2 , количество текстовых прецедентов $-\geq 2$, следование фиксированное, границы конструкций - учтены.

Результат - 6553 биграммы (69839 текстовых прецедентов). Наибольшее значение меры - 15,444 (в аддж (2) дрүнж (2) ПсДС 2×), наименьшее $--5,104$ (2 и (4551) เ (1348) ЛитС $1 \times, 1$ ЕвАс $1 \times)$. Проанализированы начальные 250 сочетаний, зафиксированные в двух и более текстах и имеющие значения в соответствии с мерой МІ от 13,859 до 5,140. Пере-

$5 M I=\log _{2} \frac{F\left(w_{1}, w_{2}\right) \times N}{F\left(w_{2}\right) \times F\left(w_{1}\right)}$, где $w_{1}$ - первый компонент, $w_{2}$ - второй компонент, $\mathrm{F}\left(w_{1}\right), \mathrm{F}\left(w_{2}\right)-$ абсолютные (независимые) частоты $w_{1}$ и $w_{2}, \mathrm{~F}\left(w_{1}, w_{2}\right)$ - абсолютная частота п-граммы в подкорпусе, $N$ - общее число словоформ в корпусе; см., например: EVERT 2004. 
чень групп биграмм, расположенных по убыванию количества примеров в группе, приведен в Приложении 2.

Выборка и систематизация биграмм, использующихся в различных текстах коллекции, позволяет сделать несколько наблюдений.

Некоторые из биграмм представляют собой сочетания, компоненты которых используются друг с другом чаще, чем с другими компонентами (значения биграмм достаточно высоки - до 13 статистических единиц): бес порока, ${ }^{6}$ очима моима, гртхх нашихъ, ты еси, г(оспод)а б(ог)а, другъ друга, всему миру, живи будете, раби недостоини, дьнесьнии день, съжежетъ огнемъ, простърг руку и некоторые другие, именно они являются устойчивыми или могут рассматриваться в качестве претендентов на устойчивые.

Некоторые из групп - предложно-падежные сочетания с существительными или местоимениями, существительное + притяжательное местоимение - очень многочисленны и с точки зрения лексического состава биграмм, и с точки зрения их использования в корпусе.

Между моделью сочетания, количеством биграмм перечня, построенных по этой модели, и степенью связанности компонентов нет зависимости: устойчивыми являются как биграммы, единичные в своей группе другъ друга, съжежеть огнемь, раби недостоини, дьнесьнии день, живи будете и др., так и входящие в группу с большим количеством примеров - бес порока, из усть, подъ криль, очима моима, люди своя.

Между тем биграммы некоторых групп тяготеют к большим или меньшим значениям меры MI; например, имеют:

1. высокие значения две биграммы по модели глагол + существительное (съжежеть огнемь, простьрг руку), все шесть биграмм с компонентом весь (весь миръ, въсеи земи и др.), три сочетания существительного с зависимым прилагательным (раби недостоини, дьнесьнии день, вечьныи б(ож)е), предикативное сиґеть свъть, личное Господь Богъ, а также конструкции из двух существительных (свъть лица, другъ друга);

2. низкие - биграммы по моделям личное местоимение + быти (mы еси, азъ есмь и др.), глагол + зависимое местоимение (помоки намь, въздасть тебъ и др.), глагольно-предложные сочетания (въниду въ, възиде на и др.), перфектные формы глагола (даль еси, възвеличиль еси), конструкции с начальными да (да омочить, да потргббю и др.), яко (гко капль, ґко мрътвъ, љко благъ) или частицами не (не могутъ, не познашя

6 В основном тексте работы примеры даны в упрощенном написании. 
и др.) или же (онъ же, тгмъ же и др.), конструкции с послелогом ради (чесо ради, сего ради), сочетания глагол + ся (събудеть ся, яви ся и многие другие - далее = мн. др.);

3. преимущественно низкие - предложно-падежные сочетания с существительными (въ глубину, въ гробъхъ, въ храмъ, въ въкъ, на одрг, на горахъ, отъ страха, отъ лица, пргжде въкъ и мн. др.) и местоимениями (по сихъ, на нь, къ тебъ и мн. др.), за единичными исключениями - до коньиза, пргљдь очима, подъ криль, бес порока, пргдъ тобою, ис тебе и некоторые др.;

4. существенно различающиеся в группе значения - сочетания $c y$ ществительное + притяжательное местоимение: 4.1. низкие - с его (главъ его, матери его, нозъ его - от 5,3 до 5,9); 4.2. в основном средние или высокие - с местоимениями твои (милость твою, десница твог, раба твоего, въьра твољ и мн. др. - от 6,2 до 10,1), свои (руцуг свои, лице свое и др. - от 6,5 до 8,9), мои (тело мое, очи мои, ср(b)д(b)це мое и др. - от 6,0 до 9,2; очима моима - 13,9), нашь (гргхх нашихъ, б(ог) в нашь и др. - от 5,8 до 9,7).

Основное количество биграмм составляют структуры, один из компонентов которых - служебные слово или местоимение, и только очень малое количество сочетаний двух знаменательных слов, репрезентирующих сложное понятие.

Сказанное позволяет сделать выводы о том, что выделенные группы биграмм, в первую очередь - с большим количеством примеров, представляют собой грамматические конструкции, построенные по некоторым моделям, заполнение позиций которых словами достаточно свободно, а сами биграммы являются реализацией некоторых достаточно устойчивых и постоянно воспроизводимых в списках глаголической коллекции конструкций, обладающих тяготеющими друг к другу в текстах грамматическими характеристиками - коллигациями. ${ }^{7}$ Одновременно с этим некоторые из биграмм на основе словоформ, компоненты которых сочетаются чаще, чем с другими словами (что проявляется в высоких значениях статистической меры MI), должны быть отнесены к статистически (коллокации), а в ряде случаев - и лингвистически (речевые формулы, обороты) устойчивым.

7 »Коллигация - это комбинация лексических и грамматических характеристик, имеющих тенденцию к совместной встречаемости« (KOČETKOVA: 302). 


\section{2. Триграммы. Словоформы}

Параметры n-грамм: тип компонентов - словоформы, количество компонентов -3 , количество текстовых прецедентов $-\geq 2$, следование фиксированное, границы конструкций - учтены.

Результат - 2226 триграмм (52 234 текстовых прецедентов). Наиболь-

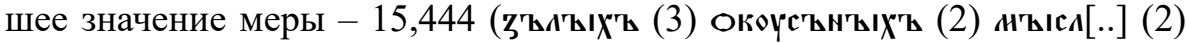
ЛитС $2 \times),{ }^{8}$ наименьшее - $-17,070$ (жє (1185) и (4551) и (4551) ЕвАс 2×). Проанализированы все сочетания, встречающиеся одновременно в двух или более текстах; их значения в соответствии с мерой МI от 6,567 до $-15,396$.

Всего триграмм, встречающихся в нескольких источниках, -47 . Все они приведены в таблице 1 Приложения.

Выборка позволяет сделать следующие заключения.

Доля триграмм, одновременно использующихся в различных текстах коллекции, по сравнению с общим количеством триграмм в выборке крайне мала. Триграммы, имеющие достаточно высокое статистическое значение, представляют собой семантически и грамматически цельные сочетания (сиъеть свъть лица, г(оспод) а б(ог)а намего и т. д.). Основными структурами первой половины списка являются именные (вb $\partial b$ несьнии день, по въсеи земи и др.) и глагольные (въниду въ домъ, будетъ въ руйъ и др.) с зависимыми компонентами различной грамматической семантики, а также одна предикативная конструкция (онъ же рече). Структуры второй части перечня представляют собой сочетания грамматически связанных (да не будетъ) и/или контекстно обусловленных ( и присно $u$ ) компонентов. Триграммы, располагающиеся в самом конце списка выборки, - сочетания находящихся в контакте служебных слов с очень большой частотностью (ся (1975) $u$ (4551) не (1283)). Большая часть повторяющихся в разных текстах триграмм встретилась только по два раза - в больших по объему ЛитС и ЕвАс или ПсДС и ЕвАс. Различна семантическая цельность компонентов сочетаний: от имени Господb Богъ, регулярно встречающегося в Псалтыри - свґтть лица (Пс. 4:7, 43:4, 88:16 и др.), конструкций с предопределенным грамматическим компонентом (въниду в домъ, и възиде на), конструкций с конкретизирующими компонентами (въ весь миръ, въ вргыя свое) и формул (онъ же

8 Где (2) - количество форм в подкорпусе, $2 \times-$ количество употреблений n-граммы в подкорпусе. 
рече) - до свободных (будеть въ руце) и контекстно обусловленных ( $a$ не въ) сочетаний. Провести границу между устойчивыми и свободными сочетаниями в перечне невозможно, расчлененность конструкций постепенно возрастает от начала к концу выборки.

Несмотря на небольшое количество семантически и грамматически цельных триграмм, их наличие позволяет говорить об определенной степени близости текстов глаголической коллекции друг другу на уровне коллокаций.

\section{3. Биграммы. Леммы}

Параметры n-грамм: тип компонентов - леммы, количество компонентов -2 , количество текстовых прецедентов $-\geq 2$, следование - свободное, границы конструкций - учтены.

Результат - 3671 биграмма (29508 текстовых прецедентов). Наибольшее значение меры - 14,859 (одтаниє (3) врачьнъ (2) ЕвАс $2 \times$ ), наименьшее - $-6,956$ (въ (4705) въ (4705) ЕвАс $2 \times$ ). Проанализированы начальные 250 сочетаний, зафиксированные в двух и более текстах; имеют значения в соответствии с мерой МІ от 10,900 до 3,458.

Основными группами перечня являются:

1) предложно-падежные сочетания с существительными: за умножение, ${ }^{9}$ до коньць (до коньца), ${ }^{10}$ до западъ, из уста (из усть), подъ нога (подъ ногама и др.), до скоть (до скота), на погребение, оть юность (оть юности), оть въстокъ, на въстание, на лоно (на лонг, на лоно), на небо, оть западъ, оть личе (оть лииа), оть печаль (оть печали), къ гробъ (къ гробу и др.), на вечеръ, отъ земля, оть страхъ (оть страха), до небо (до небеси и др.), на крило (на криль и др.), на одръ, на кръвь (на кровъхъ и др.), на мъсто, отъ гнъвъ (оть гнева), на ложе, на пргостоль (на пргсстоль), въ пргполовление, въ студеньиь, отъ адъ (отъ ада), отъ стьть (оть сътии), отъ туждь (оть туждихъ), оть чргво (оть чргва), по глава (по главь), въ оставление, въ раи, на камы (на камени), пргдљ лице, съ радость (съ радостию), къ ирькы (къ ир(ь)к(ъ)ви), пргодь око (пргдъ очима), въ притъча (въ притъчахъ), отъ старьцьь (отъ старьиь и

9 Сочетание лемм приводятся в порядке уменьшения значения меры МI.

10 В скобках для наглядности приводятся одна-две текстовые формы; при этом отсутствие после примера(ов) и в конце перечней »... и др.« означает, что приведены все грамматические конструкции конкретной биграммы и все биграммы данной группы. 
др.), въ дворъ, въ сласть, отъ градъ (оть града), на поле (на поли и др.) и местоимениями: къ тъ (къ тому), по тъ (по томъ), о сь (о семъ), у ты (у тебе), къ ты (къ тебъ);

2) именные сочетания с зависимыми притяжательными местоимениями: немощь нашь (немощь нашу и др.), гргьхъ нашь, съкровище свои (съкровища своего и др.), отьць нашь (о (ть)ци наши и др.), юность мои (юности моея и др.), заповгдь твои (заповагди твоя и др.), ольтарь твои, прьсть свои, рабъ твои, люди свои, благость твои (благости твоея и др.), душа мои (души моея и др.), пажить твои (пажити твоея и др.), глаголь мои, брать твои, милость твои (милость твою и др.), истина твои (истинг твоеи и др.), пльть мои (плъти моеи и др.), срьдьце вашь (ср(ь)д(ь)чь вашихъ), нога мои (ногама моима и др.), мои сльза (моима слъзы), мрғжа свои (мрғжу свою и др.), слово твои (словеса твог и др.), домъ свои, дъло свои (дгль своихъ), око мои (очима моима и др.), богъ нашь, гнъвъ твои, прьсть мои, срьдьце свои (сръдъиа своего и др.), душа вашь (д(оу)шя вамя), имя твои (имени твоего и др.), лице твои (лища твоего и др.), рабъ свои, нога нашь (ногы наши и др.), душа свои (д(оу)щу свою и др.), чргво твои (чргва твоего), гласъ мои, отьць мои, поношение мои (поношение мое), хрьстосъ твои, брать мои, душа нашь (д(оу)ша наша и др.), уста твои, село свои (село свое и др.), страхъ твои, свои градъ, гнъвъ свои;

3) сочетания существительного с зависимым существительным: подъножие нога (подъножие ногама и др.), кръвь хрьстосъ (крьвь х(рьст)а и др.), другъ другъ (другъ друга), домъ симонъ (дому симона), свъть лище (свгть лица), мать сынъ (с(ьl)нъ матери, м(а)ти с(ьl)ну), домъ отьиь (дому о(ть) иа), дьнь животъ (дъни живота), душа рабъ (д(оу)щу раба и др.);

4) сочетания существительного с зависимым прилагательным: $c u-$ монъ прокаженъ (симона прокаженаго), рабъ недостоинъ, животь въчьнъ, истиньнъ богъ (истинънааго б(ог)а), богъ живъ (б(ог)а жива, б(ог) а живааго);

5) глагольные конструкции с зависимыми существительными: насадити виноградъ, насадити деснииа, сътворити мьсть, възвести око (възвъсъ очи), сътворити плодъ, гстти хльбъ, творити добро, прославити имя, съпасти рабъ (с(ъ)n(а)си раба и др.), посълати духъ (посъли д(оу)хъ и др.), видгъти дъвло (видъъи дъла и др.), сътворити добро (добро сътвори и др.), а также сочетание отглагольного существительного с зависимым существительным: оставление гргхъ (оставление гргхховъ, оставление гргххмъ); 
6) глагольные конструкции с зависимыми личными местоимениями: приносити тьл (приносимъ тебъ и др.), привлещуи азъ (привльции мене и др.), угодити ты (угождьщчиими тебъ), служити азъ (служить мнт и др.), одрьжати азъ (одръжи мене и др.), поклонити ты (поклонить ти и др.), утврьдити мы (утвръди нась и др.), въсхвалити ты (въсхвалять тя и др.), помиловати азъ (помилуи мя), уготовати вы (уготованое вамь), достояти ты (достоить тебг), мьстити азь (мьсти мьнть и др.), въздати ты (въздамъ тебгь и др.), слушати азъ (слушаи мене и др.), съпасти азъ (с(ъ)n(а)си мя), даяти ты (тебе даи, тебг даюшу и др.);

7) глагольно-предложные сочетания: въстати на (въстающиимъ на и др.), причти къ, възложити на, призьргти на, съдъти на, навести на, сгодтти о, пргити на, ходити по, възвести на, съходити на, посълати къ;

8) аналитические грамматические формы: быти дльжьнь (бг дльжьнъ и др.), прискръбьнъ быти (прискръбьна еси и др.), умолити быти (умоленъ буди), подобьнъ быти (подобьно естъ), раздрушити быти (раздрушиль еси и др.), достоинь быти, продань быти (продань бысть и др.), възвеличити быти (възвеличиль есть), въложити быти (въложиль еси и др.), въренъ быти (въренъ есть и др.);

9) конструкции с местоимением вbсb: вьсь миръ, вьсь елико, вьсь пргдгль, вьсь сь (въстми сими и др.), вьсь лгто (вьсего лгта и др.), вьсь стадо (всему стаду и др.), вьсь люди (вся люди и др.), вьсь колюно (въст кольнна);

10) глаголы с ся: възиграти ся, просльзити ся, състарити ся, убояти ся, плакати ся, поклонити ся, бочти ся, възвратити ся, отъврещии ся, оправьдити ся, исповгдати ся, напльнити ся, пргклонити ся, облещи ся, уклонити ся, кляти ся, съконьчати ся, възнести ся, въселити ся, испльнити ся, възносити ся, отъяти ся, утьшити ся, обратити ся, прославити ся.

Иные группы малочисленны: глаголы в повелительном наклонении с существительным в звательной форме - помянути господь (помяни г(оспод)u), помиловати господь (помилуи г(оспод) $)$ ); предикативные конструкции - рещи господь (рече г(оспод) b), азъ въскргосити (азъ въскргишу) и некоторые другие.

Достаточно большое количество биграмм представляет собой несвязанные грамматически или семантически конструкции: ради помазати (ради помаза), ся горько, свои настави и др.

Особый интерес представляют подчинительные конструкции, в которых оба компонента выражены знаменательными частями речи и пред- 
ставляют собой в достаточно высокой степени цельные именования лиц и речевые формулы (группы 3, 4), а в группе 5 - конструкции с наиболее актуальной для текстов лексико-семантической связью глаголов и зависимых существительных.

Устойчивость этих примеров доказывается не только смысловой и грамматической связью компонентов и использованием их в нескольких текстах коллекции, но и ограниченной сочетаемостью многих из них в рукописях:

симонъ прокажень / курингнинъ / ионинъ / нарицаемъ / етеръ / свои; жсивоть вгчьнъ / бесконьчьнь / мои / твои / нашь;

рабъ недостоинь / тьшть / лукавъ / зъль / гргиьнь / продань / боляшть / добрь / блаженъ / благъ / вторьнь / господьнь / свои / твои / мои / инъ / mb.

Глагол сътворити и его формы в коллекции имеют, кроме присутствующих в выборке мьсть, плодъ, добро, относительно небольшой круг и других зависимых слов - свгтило, брание, погребение, избавление, бракъ, память, телецьь, чюдо, льсть, любы, небо, часъ, зъло, вргмя, животь, благо, съвъть, чловъкъ, милость, ничьсоже, вься. При этом сочетания с мьсть, плодъ, добро с глаголом сътворити имеют наибольший статистический вес по сравнению с другими. Глагол насадити имеет только три зависимых существительных - корень, виноградъ и десница, из них два последних - среди слов, с которым насадити используется в нескольких рукописях коллекции. Глагол възвести - два зависимых существительных - очи, хльбъ; пьсти два - мана, хльбъ; съпасти три - душа, рабъ, люди; прославити три - имя, сынъ, отьцьь; творити несколько больше - делание, шествие, безаконие, плодъ, чюдеса, знамение, добро, дъло, слово, дъло, милость; посьлати также - мостьи, сылость, вои, избавление, источьникъ, стргла, брашьно, духъ, свъть, сила, слово, рабъ, сынъ, исусъ; видгти также - видгние, юнома, камень, огнь, съмрьть, исусъ, хрьстосъ, безаконие, коньцьь, лице, гробъ, море, духъ, свъть, чловъкъ, отьць, ученикъ, сынъ.

Высокие статистические значения сочетаний других групп свидетельствует об активности некоторых грамматических моделей - коллигаций »предлог + существительное«, »глагол + предлог« и др., а лексический состав - о повторяемости их лексической реализации в разных глаголических рукописях. 


\section{4. Триграммы. Леммы}

Параметры n-грамм: тип компонентов - леммы, количество компонентов -3 , количество текстовых прецедентов $-\geq 2$, следование - свободное, границы конструкций - учтены.

Результат - 1973 триграммы (15547 текстовых прецедентов). Наибольшее значение меры - 9,159 (трєвовати (13) стыравию (4) врачь (6) ЕвАс 2×), наименьшее - -22,491 (и (15437) и (15437) нє (15437) ПсДС 6×). Проанализированы начальные 100 сочетаний, зафиксированные в двух и более текстах; имеют значения в соответствии с мерой МI от $-0,686$ до -10,770. Несмотря на низкие статистические значения этих триграмм (а соответственно расположение в полной выборке в 7-м десятке), находящиеся в позициях 1-50 n-граммы, встречающиеся в нескольких текстах, представляют собой семантически и грамматически цельные конструкции или их части:

предикативные - иже насади десница, онъ же рече, нғсмъ бо достоинъ, съказа мьнт г(оспод) ь, въси напишуть ся;

именные - плодъ чргвв тввоего, слово твоея истины / словесъ твоихъ истина, въ весь миръ, вся дьни жсивота, душа раба твоего, г(осподи милость твою, [глаголи] мирь на люди, г(осподи б(ог)ь нашъ, пргдъ въстьми людьми, подъ нозьъ его, въ ногахъ нашихъ, [помьни] сънемъ твои иже [сьтяжа];

глагольные - очима моима сльзы [точити], възвратятъ ся въспятъ, утврьди силою твоею, [ангеломъ] своимъ заповъсть о тебг, еси къ тому, пришедъ въсели ся, исповъдаю ся тебъ, поклони ти ся, еси на н(е) б(е)сехъ, помилуи мя г(осподи, придетъ къ тебгь, нғьсть бо д(оу)ха, уготоваль еси пргдъ [мъною], въложиль еси въ;

именные парные - слънъце и луна, въстокъ и западъ, [въ] родъ и родъ, гора и хльмъ, дьнъ и нощь, петра и павла, нынъ и присно;

наречные - и коль красьно;

предложно-падежные - $и$ за умножение [безакония], по сргдљ же, $u$ на въстание;

иные - [ц(вса)ръ] велеи по всти [земи], къ тому и, ся къ ир(ь)к(ъ)ви, ни единъ оть.

Просмотр позиций 51-100 выборки добавил к сочетаниям немного: въ дому о (ть)иа, въ сръдъии своемъ, сътвориль еси намъ, и плодъ сътвори, въ всемъ мирг, о (ть)иа и с(ь)на, г(оспод) и б(о)же мои.

Использование параметра »Следование« запросной формы с целью нахождения сочетаний, компоненты которых могут находиться в любой последовательности друг к другу, привело в ряде случаев к объединению к од- 
ной триграмме разных моделей: въ пръстъ свою / пръста своего въ, съказа мьнг г(оспод) $\mathbf{~ / ~ с ъ к а ж с и ~ м ъ н ъ ~ г ~ ( о с п о д ) ~} и$, въ ногахъ нашихъ / ногы нашя въ.

Таким образом, выборка триграмм на основе лемм дает существенно иные результаты, чем выборка на основе текстовых прецедентов: подавляющая часть первых нескольких десятков сочетаний представляет собой грамматически и семантически цельные конструкции или их части. Использование этих конструкций в различных глаголических рукописях позволяет с большой долей вероятности считать их не свободными, а цельными, какие бы причины ни были тому причиной - интертекстуальные, речевые или языковые.

\section{4. ЗАКЛЮЧЕНИЕ}

Извлечение биграмм и триграмм на основе текстовых форм и лемм из глаголической коллекции исторического корпуса »Манускрипт: славянское письменное наследие« (manuscripts.ru) с помощью статистической меры Mutual information и их анализ дает право говорить о высокой информативности выборок для поиска с высокой степенью вероятности цельных сочетаний. Ограничение перечней анализируемых n-грамм примерами, встречающимися в нескольких рукописях, позволило не только выявить круг сочетаний, характеризующих коллекцию в целом, но и с большой степенью вероятности предположить, что цельность сочетаний, имеющих высокое статистическое значение, одновременно является и результатом их свойств в одном тексте, и, в связи с воспроизводимостью в нескольких, должна рассматриваться как общетекстовая и надтекстовая для проанализированных рукописей.

Анализ материала показал, что провести границу между цельными и свободными сочетаниями только на основании статистического значения невозможно. Тем не менее сочетания, имеющие максимальные значения в ограниченной определенными параметрами выборке (удаление единичных сочетаний, приведение словоформ к леммам) и повторяющиеся в нескольких текстах, следует с высокой долей вероятности признавать значимыми, цельность которых определяется семантической и грамматической связностью компонентов.

Варьирование параметров n-грамм позволяет обнаружить как сочетания с лексико-грамматической связностью компонентов - коллокации, так и морфолого-синтаксические модели, представленные в коллекции частотными реализациями, - коллигации. 
Несмотря на то, что использование статистической меры Mutual Information для извлечения редких цельных сочетаний в коллекции глаголических рукописей показало высокую эффективность и результативность, окончательная оценка степени устойчивости большей части сочетаний или грамматических моделей может быть осуществлена с привлечением и других, собственно лингвистических методов.

\section{БЛАГОДАРНОСТИ}

Работа выполнена при финансовой поддержке Российского фонда фундаментальных исследований (РФФИ) в рамках проекта »Лингвостатистический анализ однокомпонентных и многокомпонентых лексических единиц исторического корпуса “Манускрипт”" (проект № 18/012/00463)

\section{СОКРАЩЕНИЯ / ABBREVIATIONS}

БРАН / BRAN = Библиотека Российской академии наук, С.-Петербург. / Library of the Russian Academy of Sciences, St. Petersburg.

PAH / RAN = Российская академия наук. / Russian Academy of Sciences.

$\mathrm{AAH} / \mathrm{AAN}=$ Австрийская Академия наук / Austrian Academy of Sciences.

РНБ / RNB = Российская национальная библиотека, С.-Петербург. / National Library of Russia, St. Petersburg.

НБУ / NBU = Национальная библиотека Украины имени В. И. Вернадского, Киев / National Library of Ukraine named after V. I. Vernadsky, Kiev

\section{ИСТОЧНИКИ}

ЕвАс = Ассеманиево Евангелие, Ватиканская (Апостолическая) библиотека, Slav. 3 Glag., X/ХІ вв., 158 л. Подг., Р. Ф. ТУБИЛОВА; В. А. БАРАНОВ (Ижевский государственный технический университет). URL: http:// manuscripts.ru/mns/main?p_text=56673793 (15.5.2018).

ПсДС = Псалтырь Димитрия Синайского, Синай/Египет, Монастырь св. Екатерины, Cod. Sin. slav. 3/N, третья четверть ХІ в., 145 л. Подг. А. Н. СОБОЛЕВ (РАН/ААН/Марбургский университет); М. МАКРОБЕРТ (Оксфордский университет); М. ГАУ (Венский технический университет); под ред. Х. МИКЛАСА (Венский университет). URL: http://manuscripts. $\mathrm{ru} / \mathrm{mns} /$ portal.main?pl=42 (15.5.2018). 
ЛитС = Литургиарий (ранее ММссал«), Синай/Египет, Монастырь св. Екатерины, Cod. Sin. slav. 5/N, вторая четверть XI в., около 80 л. Подг. В. САДОВСКИ; Д. ХЮРНЕР; Ф. ВАНДЛ; Х. МИКЛАС, под ред. Х. МИКЛАСА (Венский университет). URL: http://manuscripts.ru/ mns/portal.main?pl=67 (15.5.2018).

ЛитСФр = Литургиарий, фрагмент (»Синайский служебник«, »Листки Крылова и Успенского«), Санкт-Петербург, БРАН 24.4.8 (Срезн. 55) \& РНБ, Глаг. 2, вторая четверть ХІ в., 3 л. Подг. Х. МИКЛАС (Венский университет); В. А. БАРАНОВ (Ижевский государственный технический университет); под ред. Х. МИКЛАСА (Венский университет). URL: http://manuscripts.ru/mns/portal.main?p1=69 (15.5.2018).

МедЛ = Медииинские листки, Синай/Египет, Монастырь св. Екатерины, Cod. Sin. slav. 3/N, посл. четв. ХІ в., 2 л. Подг. Х. МИКЛАС; Д. ХЮРНЕР, под редакцией Х. Микласа (Венский университет). URL: http://manuscripts.ru/mns/portal.main?p1=59 (15.5.2018).

МинС = Минея синайская, Синай/Египет, Монастырь св. Екатерины, Cod. Sin. slav. 4/N, последняя четверть ХІ в., 2 л. Подг. Х. МИКЛАС; Д. ХЮРНЕР (Венский университет); М. ГАУ (Венский технический университет); под ред. Х. Микласа (Венский университет). URL: http://manuscripts.ru/mns/portal.main?p1=48 (15.5.2018).

КЛ = Киевские листки (»Киевский миссал«), НБУ, ДА/П. 328, X/XI в. и XII в., отрывок, 7 л. Подг. В. А. БАРАНОВ (Ижевский государственный технический университет). URL: http://manuscripts.ru/ mns/main?p_text=61350133 (15.5.2018).

Час = Часослов, фрагмент, Синай/Египет, Монастырь св. Екатерины, первая четверть ХІ в., 1 л. Подг. Н. ГЛИБЕТИЧ (Еврейский университет, Иерусалим); под ред. Х. Микласа (Венский университет). URL: http://manuscripts.ru/mns/portal.main?p1=66 (15.5.2018).

\section{ЛИТЕРАТУРА}

ÂGUNOVA; PIVOVAROVA 2010. = ЯГУНОВА, Е. В.; Л. М. ПИВОВАРОВА. 2010. Природа коллокаций в русском языке. Опыт автоматического извлечения и классификации на материале новостных текстов. Сборник научно-технической информаиุuи. Сер. 2, № 6. URL: http://medialing.spbu.ru/upload/files/file_1394529742_4311. pdf, http://webground.su/services.php?param=priroda_collac\&part=priroda_collac. htm (15.5.2018). [ÂGUNOVA, E. V.; L. M. PIVOVAROVA. 2010. Priroda kollokacij v russkom âzyke. Opyt avtomatičeskogo izvlečeniâ i klassifikacii na materiale novostnyh tekstov. Sbornik nauchno-tekhnicheskoj informacii. Ser. 2, № 6. URL: http://medialing.spbu.ru/upload/files/file_1394529742_4311.pdf, http://webground. su/services.php?param=priroda_collac\&part=priroda_collac.htm (15.5.2018).] 
ÂGUNOVA; PIVOVAROVA 2013. = ЯГУНОВA, Е. В.; Л. М. ПИВОВАРОВА. 2013. От коллокаций к конструкциям. Русский язык: конструкиионные и лексико-семантические подходы. С. С. Сай (ред.). Санкт-Петербург: Труды Института лингвистических исследований PAH. URL: https://www.academia.edu/4461901/ ОТ_КОЛЛОКАЦИЙ_К_КОНСТРУКЦИЯМ (15.5.2018). [ÂGUNOVA, E. V.; L. M. PIVOVAROVA. 2013. Ot kollokacij k konstrukciâm. Russkij âzyk: konstrukcionnye i leksiko-semantičeskie podhody. S. S. Saj (red.). Sankt-Peterburg: Trudy Instituta lingvističeskih issledovanij RAN. URL: https://www.academia.edu/4461901/ ОТ_КОЛЛОКАЦИЙ_К_КОНСТРУКЦИЯМ (15.5.2018).]

BARANOV 2014. = БАРАНОВ, В. А. 2014. Организация поиска и демонстрации коллокаций в корпусе »Манускрипт«. Проблемы истории, филологии, культуры 3 (45): 275-277. [BARANOV, V. A. 2014. Organizaciâ poiska i demonstracii kollokacij v korpuse »Manuskript«. Problemy istorii, filologii, kul'tury 3 (45): 275-277.]

BARANOV 2015. = БАРАНОВ, В. А. 2015. Исторический корпус как цель и инструмент корпусной палеославистики. Scripta \& e-Scripta 14-15: 39-62. URL: https:// drive.google.com/file/d/0BwBejXXryRcROVQ4TnlpZFh6am8/view?usp=sharing (15.5.2018). [BARANOV, V. A. 2015. Istoričeskij korpus kak cel' i instrument korpusnoj paleoslavistiki. Scripta \& e-Scripta 14-15: 39-62. URL: https://drive.google.com/ file/d/0BwBejXXryRcROVQ4TnlpZFh6am8/view?usp=sharing (15.5.2018).]

BARANOV 2016.a. = БАРАНОВ, В. А. 2016.а. Модуль n-грамм исторического корпуса »Манускрипт«: структурные и лингвистические параметры. Научное наследие В. А. Богородиџкого и современный вектор исследований Казанской лингвистической школьы. 1. Казань: Изд-во Казан. ун-та, 50-61. URL: https://drive.google. com/file/d/0BwBejXXryRcROHc5T3YxTENhLUk/view (15.5.2018). [BARANOV, V. A. 2016.a. Modul' n-gramm istoričeskogo korpusa »Manuskript«: strukturnye i lingvističeskie parametry. Naučnoe nasledie V. A. Bogorodickogo i sovremennyj vektor issledovanij Kazanskoj lingvističeskoj školy. 1. Kazan': Izd-vo Kazan. un-ta, 50-61. URL: https://drive.google.com/file/d/0BwBejXXryRcROHc5T3YxTENhLUk/view (15.5.2018).]

BARANOV 2016.b. $=$ БАРАНОВ, В. А. 2016.б. Опыт создания модуля n-грамм системы »Манускрипт« и оценки эффективности его использования для поиска коллокаций в корпусе М. В. Ломоносова. Интеллектуальные системы в производстве 4 (31): 124-131. URL: https://drive.google.com/file/d/0BwBejXXryRcRV3ZpemZKcC1CMTQ/view (15.5.2018). [BARANOV, V. A. 2016.b. Opyt sozdaniâ modulâ n-gramm sistemy »Manuskript«i ocenki èffektivnosti ego ispol'zovaniâ dlâ poiskakollokacij v korpuse M. V. Lomonosova. Intellektual'nye sistemy v proizvodstve 4 (31): 124131. URL: https://drive.google.com/file/d/0BwBejXXryRcRV3ZpemZKcC1CMTQ/ view (15.5.2018).]

BARANOV 2017. = БАРАНОВ, В. А. 2017. Инструменты и методика поиска коллокаций в историческом корпусе »Манускрипт« (на примере глаголических рукописей). Filologija 68: 17-49. [BARANOV, V. A. 2017. Instrumenty i metodika poiska kollokacij v istoričeskom korpuse »Manuskript« (na primere glagoličeskih rukopisej). Filologija 68: 17-49.] 
EVERT, S. 2004. Association Measures. Computational Approaches to Collocations. URL: http://collocations.de/AM/index.html (15.5.2018).

HOHLOVA 2008. = ХОХЛОВА, М. В. 2008. Экспериментальная проверка методов выделения коллокаций. Slavica Helsingiensia 34. Инструментарий русистики: Kopnyсные подходыл. А. Мустайоки, М. В. Копотева, Л. А. Бирюлина, Е. Ю. Протасовой (ред.), 343-357. URL: http://www.helsinki.fi/slavicahelsingiensia/preview/ sh34/pdf/21.pdf (15.5.2018). [HOHLOVA, M. V. 2008. Èksperimental'naâ proverka metodov vydeleniâ kollokacij. Slavica Helsingiensia 34. Instrumentarij rusistiki: Korpusnye podhody. A. Mustajoki, M. V. Kopoteva, L. A. Birûlina, E. U. Protasovoj (red.), 343-357. URL: http://www.helsinki.fi/slavicahelsingiensia/preview/sh34/ pdf/21.pdf (15.5.2018).]

KOČETKOVA. = КОЧЕТКОВА, Н. А. Статистические языковые методы. Коллокации и коллигации. Cyberleninka.ru. URL: http://cyberleninka.ru/article/n/statisticheskie-yazykovye-metody-kollokatsii-i-kolligatsii (15.5.2018). [KOČETKOVA, N. A. Statističeskie âzykovye metody. Kollokacii i kolligacii. Cyberleninka.ru. URL: http:// cyberleninka.ru/article/n/statisticheskie-yazykovye-metody-kollokatsii-i-kolligatsii (15.5.2018).]

LUKAŠEVIČ; LOGAČEV 2010. = ЛУКАШЕВИЧ, Н. В.; Ю. М. ЛОГАЧЕВ. 2010. Комбинирование признаков для автоматического извлечения терминов. Bblчислительные методы и программирование 2: 108-116. URL: https://elibrary.ru/ download/elibrary_15272886_42034432.pdf (15.5.2018). [LUKAŠEVIČ, N. V.; Û. M. LOGAČEV. 2010. Kombinirovanie priznakov dlâ avtomatičeskogo izvlečeniâ terminov. Vyčislitel'nye metody i programmirovanie 2: 108-116. URL: https://elibrary.ru/ download/elibrary_15272886_42034432.pdf(15.5.2018).]

ONAL 2017. = ОНАЛ, И. О. 2017. »Коллокация« и »коллигация«: динамика развития значений. Язык и культура: Сборник материалов ХХХ Международной научно-практической конференции (С. С. Чернов (ред.), 33-39. URL: https:// elibrary.ru/download/elibrary_30001229_26220986.pdf (15.5.2018). [ONAL, I. O. 2017. »Kollokaciâ« i »kolligaciâ«: dinamika razvitiâ značenij. Âzyk i kul'tura: Sbornik materialov XXX Meždunarodnoj naučno-praktičeskoj konferencii (S. S. Černov (red.), 33-39. URL: https://elibrary.ru/download/elibrary_30001229_26220986.pdf (15.5.2018).]

PECINA, P.; P. SCHLESINGER. 2006. Combining association measures for collocation extraction. Annual Meeting of the Association for Computational Linguistics (ACL 2006). Sydney: ACM, 651-658.

VLAVACKAÂ 2011. = ВЛАВАЦКАЯ, М. В. 2011. Система базовых понятий комбинаторной лингвистики. Мир науки, культуры, образования 1: 32-38. URL: https:/elibrary.ru/download/elibrary_17783474_54708535.pdf (15.5.2018). [VLAVACKAÂ, M. V. 2011. Sistema bazovyh ponâtij kombinatornoj lingvistiki. Mir nauki, kul'tury, obrazovaniâ 1: 32-38. URL: https://elibrary.ru/download/elibrary_17783474_54708535. pdf (15.5.2018).]

ZALESSKAÂ 2014. = ЗАЛЕССКАЯ, В. В. 2014. Программа выявления в тексте двучленных статистически значимых осмысленных коллокаций (на материале 
русского языка). Технологии информаџионного общества в науке, образовании и культуре: сборник научных статей. Труды XVII Всероссийской объединенной конференции »Интернет и современное общество« (IMS-2014). Санкт-Петербург, 283-289. URL: http://ojs.ifmo.ru/index.php/IMS/article/viewFile/267/263 (15.5.2018). [ZALESSKAÂ, V. V. 2014. Programma vyâvleniâ v tekste dvučlennyh statističeski značimyh osmyslennyh kollokacij (na materiale russkogo âzyka). Tehnologii informacionnogo obŝestva $v$ nauke, obrazovanii i kul'ture: sbornik naučnyh statej. Trudy XVII Vserossijskoj ob"edinennoj konferencii »Internet $i$ sovremennoe obŝestvo" (IMS-2014). Sankt-Peterburg, 283-289. URL: http://ojs.ifmo.ru/index.php/ IMS/article/viewFile/267/263 (15.5.2018).]

ZAHAROV; HOHLOVA 2014. = ЗАХАРОВ, В. П.; М. В. ХОХЛОВА. 2014. Выделение терминологических словосочетаний из специальных текстов на основе различных мер ассоциации. Технологии информационного общества в науке, образовании и культуре: сборник научных статей. Труды XVII Всероссийской объединенной конференции »Интернет и современное общество" (IMS-2014). Санкт-Петербург, 290-293. URL: http://ojs.ifmo.ru/index.php/IMS/article/viewFile/268/264 (15.5.2018). [ZAHAROV, V. P.; M. V. HOHLOVA. 2014. Vydelenie terminologičeskih slovosočetanij iz special'nyh tekstov na osnove različnyh mer associacii. Tehnologii informacionnogo obŝsestva v nauke, obrazovanii i kul'ture: sbornik naučnyh statej. Trudy XVII Vserossijskoj ob"edinennoj konferencii »Internet i sovremennoe obsestvo« (IMS-2014). Sankt-Peterburg, 290-293. URL: http://ojs.ifmo.ru/index.php/ IMS/article/viewFile/268/264 (15.5.2018).]

ZHANG, Z.; J. IRIA; CH. BREWSTER; F. CIRAVEGNA. 2008. A Comparative Evaluation of Term Recognition Algorithms. Proceedings of the Sixth International Conference on Language Resources and Evaluation (LREC'08). Marrakech. 

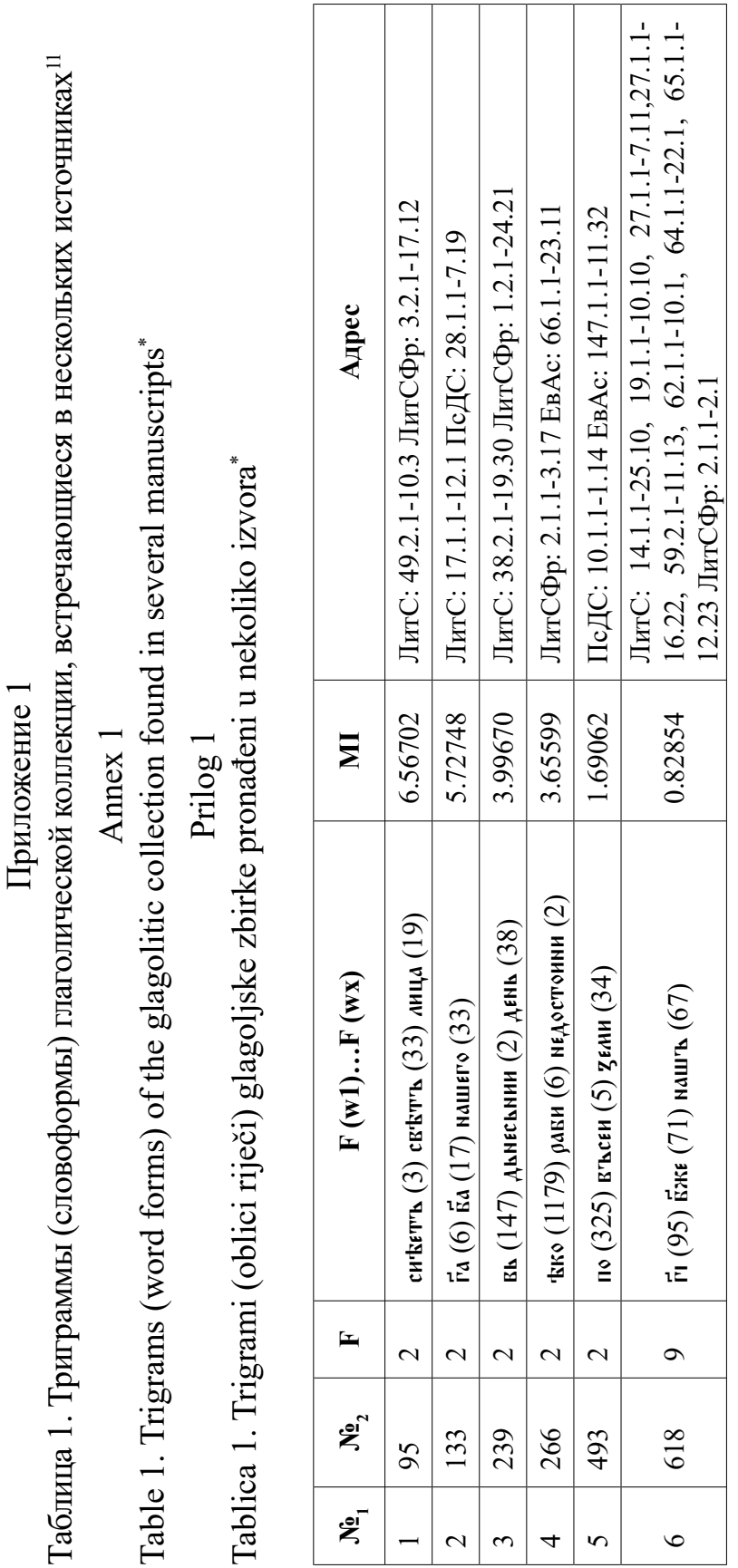

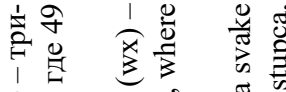

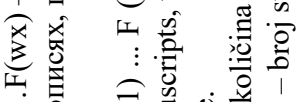

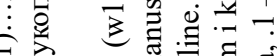

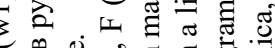

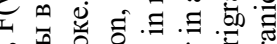

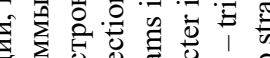

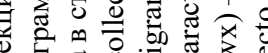

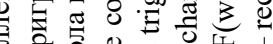

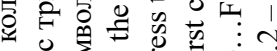
क o

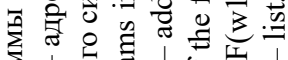

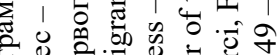

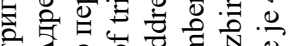

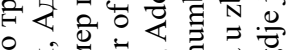

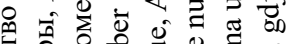

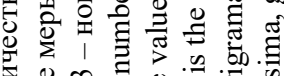

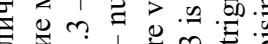

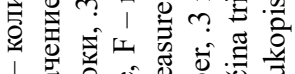
1 屈 ज记

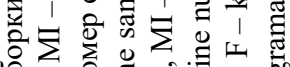

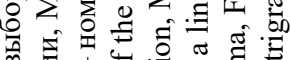
要

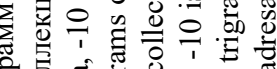

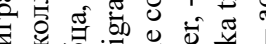
党 웅

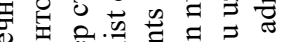

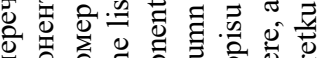
일 울

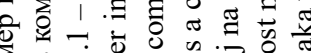
文

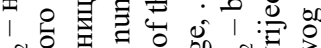
육

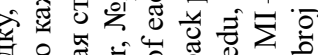
辰 实 है

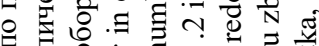

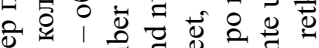

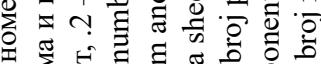

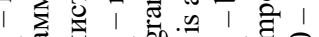

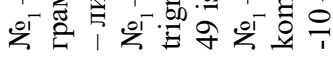




\begin{tabular}{|c|c|c|c|c|c|c|c|c|c|c|c|c|c|c|c|}
\hline$\frac{\mathscr{E}}{\mathbb{Z}^{\prime}}$ & 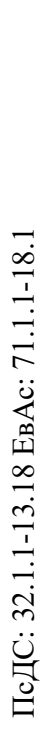 & 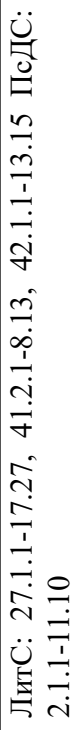 & 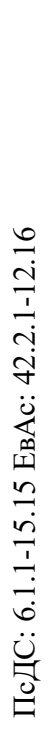 & 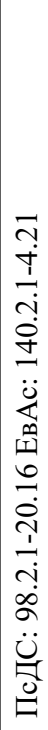 & 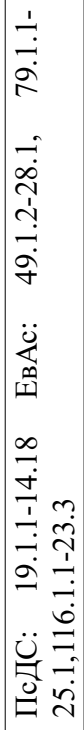 & 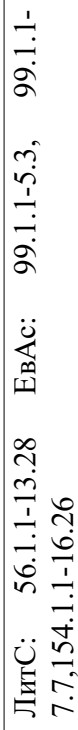 & 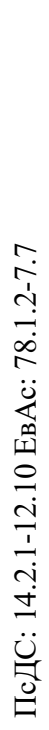 & 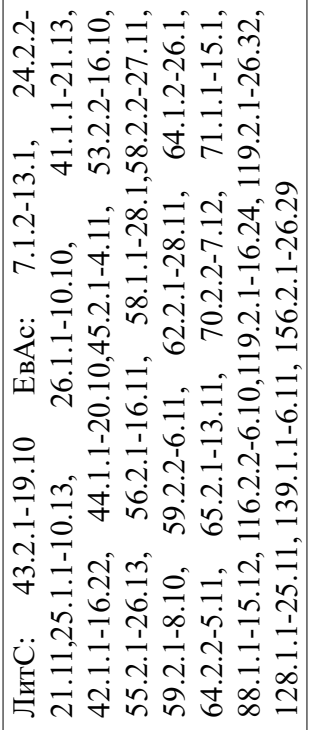 & 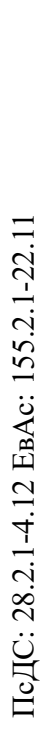 & 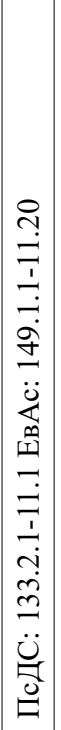 & 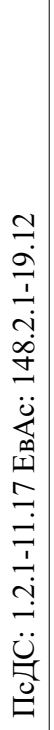 & 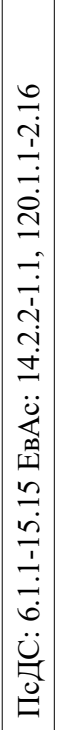 & 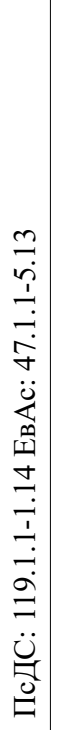 & 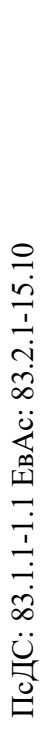 & 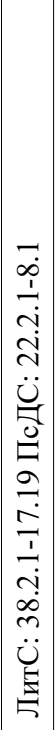 \\
\hline$\Sigma$ & 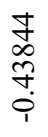 & $\begin{array}{l}\stackrel{0}{\hat{a}} \\
\stackrel{6}{-} \\
\stackrel{1}{1}\end{array}$ & $\begin{array}{l}0 \\
20 \\
2 \\
\infty \\
i \\
i\end{array}$ & 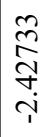 & $\begin{array}{l}\stackrel{0}{+} \\
\stackrel{2}{6} \\
\stackrel{1}{i}\end{array}$ & $\begin{array}{l}\overrightarrow{+} \\
\stackrel{2}{\sim} \\
\stackrel{r}{1}\end{array}$ & $\begin{array}{l}\infty \\
\stackrel{\alpha}{\alpha} \\
\sigma \\
\stackrel{1}{1}\end{array}$ & $\begin{array}{l}8 \\
\stackrel{+}{+} \\
\stackrel{5}{0} \\
\dot{+}\end{array}$ & 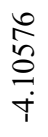 & $\begin{array}{l}\vec{a} \\
\vec{\sigma} \\
\dot{r}\end{array}$ & 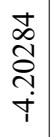 & 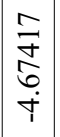 & 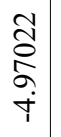 & 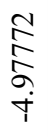 & 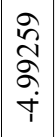 \\
\hline$\underset{E}{\stackrel{E}{E}}$ & 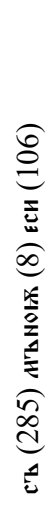 & 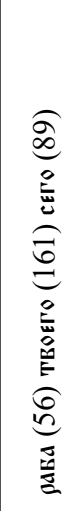 & 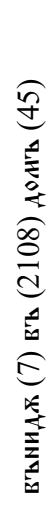 & 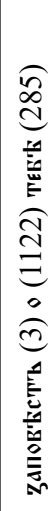 & 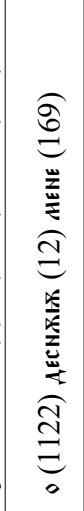 & 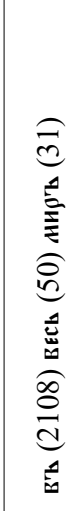 & 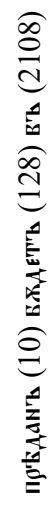 & 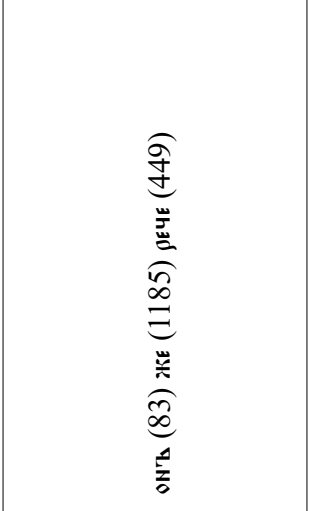 & 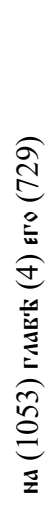 & 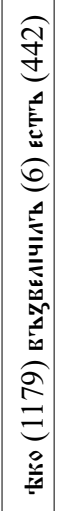 & 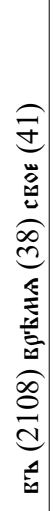 & 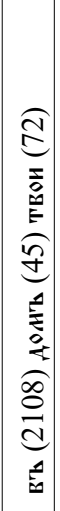 & 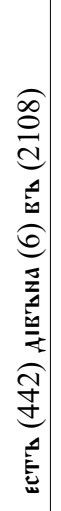 & 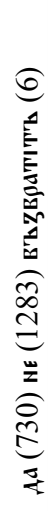 & 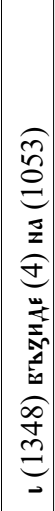 \\
\hline 工x & N & $\nabla$ & $N$ & $\sim$ & $\nabla$ & $\nabla$ & N & ๙ิ & $N$ & $\sim$ & $N$ & $m$ & $\sim$ & $N$ & $\sim$ \\
\hline$\frac{0^{N}}{5}$ & $\underset{\infty}{\infty}$ & 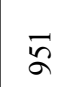 & $\underline{0}$ & $\stackrel{6}{=}$ & $\stackrel{\sim}{\beth}$ & ปे & 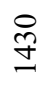 & चे & 疋 & $\left|\begin{array}{l}\infty \\
0 \\
0 \\
\pm\end{array}\right|$ & $\begin{array}{l}\text { Õ } \\
\stackrel{D}{ \pm}\end{array}$ & $n$ & ర్ర & $\stackrel{\infty}{0}$ & $\stackrel{8}{8}$ \\
\hline$\varepsilon^{\circ}$ & $r$ & $\infty$ & 0 & $=$ & - & - & - & - & $\cong$ & $\because$ & 工 & $\cong$ & $\stackrel{2}{2}$ & હे & $\vec{\sim}$ \\
\hline
\end{tabular}




\begin{tabular}{|c|c|c|c|c|c|c|c|c|c|c|c|c|c|c|c|c|c|c|c|}
\hline$\frac{\mathscr{̋}}{\frac{\mathscr{K}}{4}}$ & 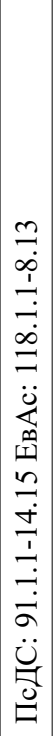 & 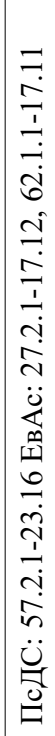 & 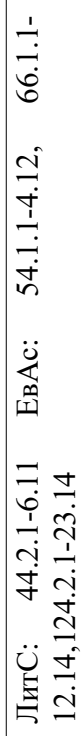 & 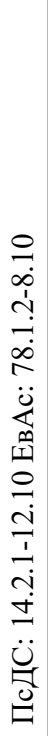 & 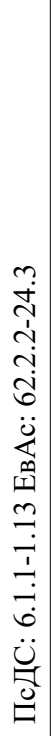 & 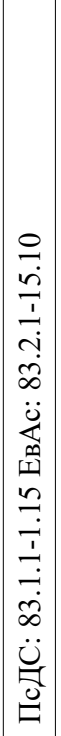 & 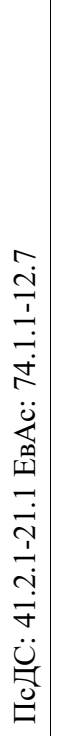 & 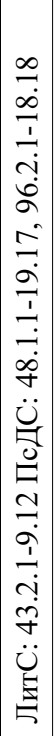 & 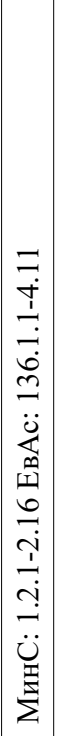 & 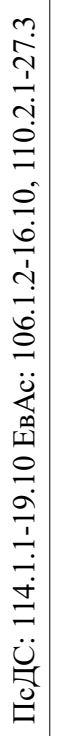 & 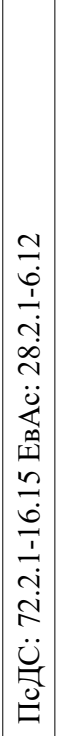 & 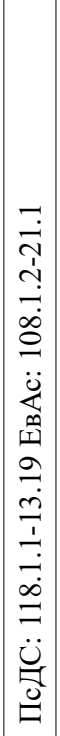 & 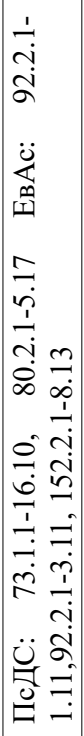 & 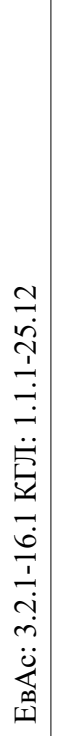 & 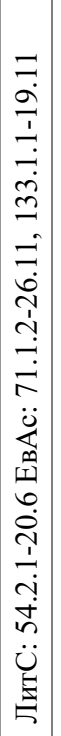 & 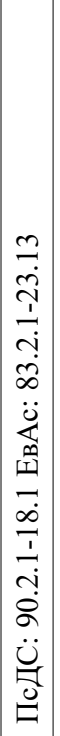 & 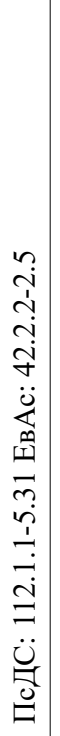 & 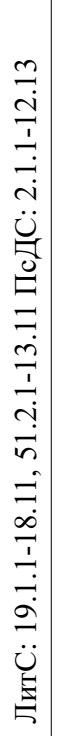 & 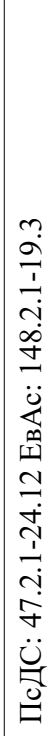 \\
\hline $\bar{\Sigma}$ & 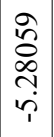 & $\begin{array}{l}a \\
\grave{2} \\
\grave{a} \\
\dot{r} \\
i\end{array}$ & 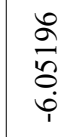 & $\begin{array}{l}\vec{\Omega} \\
\infty \\
0 \\
\stackrel{\varphi}{0}\end{array}$ & 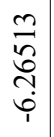 & $\begin{array}{c}0 \\
0 \\
0 \\
\forall \\
\forall \\
1 \\
1\end{array}$ & 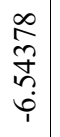 & $\begin{array}{l}0 \\
0 \\
\infty \\
0 \\
\hat{0} \\
1\end{array}$ & $\begin{array}{l}0 \\
2 \\
\frac{1}{1} \\
\frac{\pi}{1}\end{array}$ & 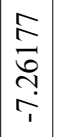 & $\begin{array}{c}\hat{\infty} \\
0 \\
T \\
T \\
T\end{array}$ & 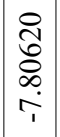 & $\frac{\stackrel{N}{n}}{\hat{n}}$ & 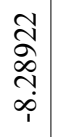 & 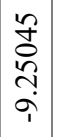 & $\begin{array}{l}n \\
\hat{N} \\
\tilde{\sigma} \\
\sigma\end{array}$ & \begin{tabular}{l}
$\hat{\widehat{b}}$ \\
\multirow{2}{*}{} \\
$\stackrel{i}{i}$
\end{tabular} & 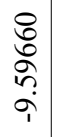 & $\begin{array}{l}\stackrel{2}{\alpha} \\
\stackrel{\sigma}{a} \\
\sigma\end{array}$ \\
\hline 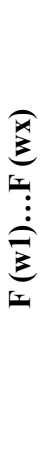 & 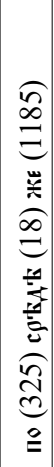 & 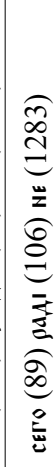 & 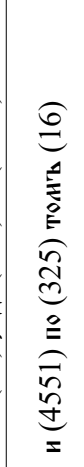 & 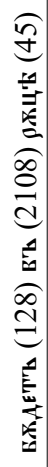 & 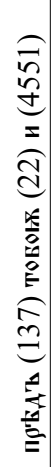 & 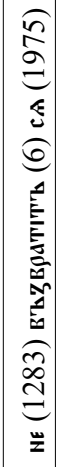 & 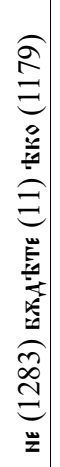 & 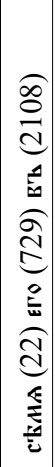 & 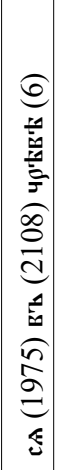 & 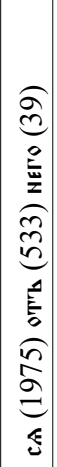 & 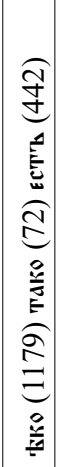 & 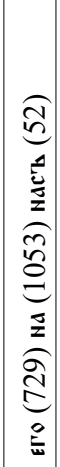 & 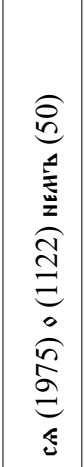 & 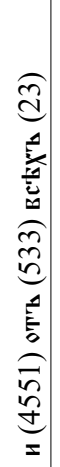 & 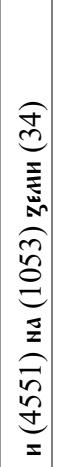 & 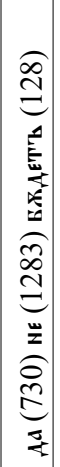 & 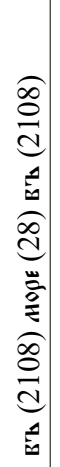 & 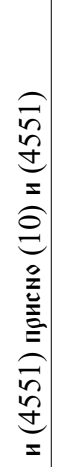 & 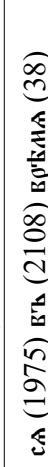 \\
\hline$E$ & $\sim$ & $m$ & $\nabla$ & $\sim$ & $\sim$ & $N$ & $\sim$ & $m$ & $\sim$ & $m$ & $\sim$ & $N$ & in & $\sim$ & $m$ & $\sim$ & $N$ & $m$ & $N$ \\
\hline$\frac{01}{\zeta}$ & 光 & ఏ્త & 을 & $\stackrel{n}{\Sigma}$ & $\stackrel{8}{\infty}$ & $\frac{\nabla}{\infty}$ & $\begin{array}{l}\infty \\
\infty \\
\infty\end{array}$ & $\stackrel{\circ}{\infty}$ & $\frac{m}{\sigma}$ & 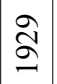 & 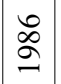 & $\widehat{\widehat{\sigma}}$ & ণి & 离 & $\overline{\overline{0}}$ & 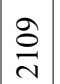 & $\exists$ & $\underset{\Xi}{\simeq}$ & $\stackrel{\dot{m}}{\sim}$ \\
\hline$\frac{\text { oi }}{\zeta}$ & $\widetilde{N}$ & $\sim$ & $\sqrt{2}$ & $\sim$ & $\sim$ & $\widetilde{\sim}$ & $\sim$ & ते & m & $\bar{m}$ & $\widetilde{n}$ & $m$ & m & $\stackrel{n}{m}$ & b & $\hat{m}$ & $\stackrel{\infty}{m}$ & ले & \& \\
\hline
\end{tabular}




\begin{tabular}{|c|c|c|c|c|c|c|c|}
\hline$\frac{\mathscr{E}}{\frac{\pi}{K}}$ & 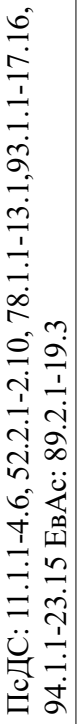 & 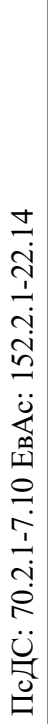 & 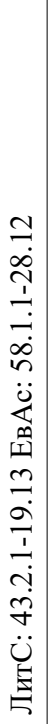 & 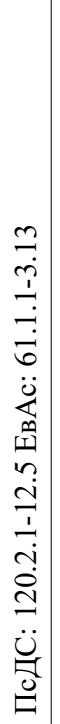 & 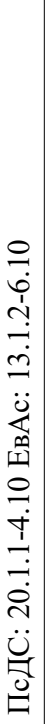 & 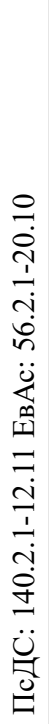 & 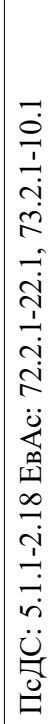 \\
\hline$\sum$ & 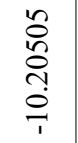 & 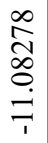 & 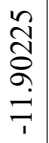 & \begin{tabular}{l}
2 \\
$\infty$ \\
$\infty$ \\
$\infty$ \\
$\infty$ \\
$\dot{1}$ \\
\hdashline
\end{tabular} & 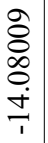 & 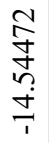 & 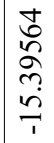 \\
\hline 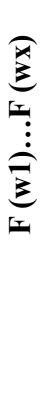 & 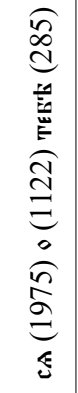 & 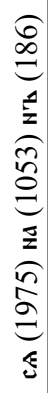 & 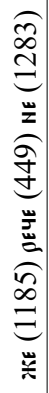 & 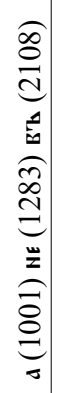 & 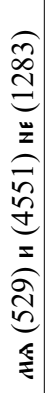 & 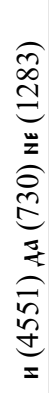 & 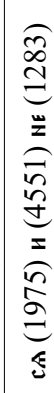 \\
\hline$[x$ & 0 & $N$ & $N$ & N & $\sim$ & $N$ & $n$ \\
\hline$\frac{\text { oin }}{5}$ & 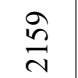 & $\frac{\infty}{\stackrel{\infty}{\sim}}$ & $\frac{\check{n}}{\sim}$ & $\frac{\curvearrowright}{\vec{\lambda}}$ & 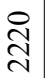 & $\begin{array}{l}\overrightarrow{\widetilde{N}} \\
\text { }\end{array}$ & İ \\
\hline$\frac{\text { oi }}{2}$ & $\vec{\gamma}$ & $\stackrel{\mathcal{F}}{ }$ & $\stackrel{\vartheta}{\sigma}$ & 导 & 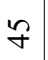 & \& & f \\
\hline
\end{tabular}


Приложение 2

Группы из первых 250 биграмм, построенных на основе словоформ

Appendix 2

Groups of the first 250 bigrams built on the basis of word forms

Dodatak 2

Grupe od prvih 250 bigrama, oblikovanih na temelju oblika riječi

ПРЕДЛОГ + СУЩЕСТВИТЕЛЬНОЕ $(55-360 \times):{ }^{12}$ кєс (9) порөка (2) $2 \times,,^{13}$

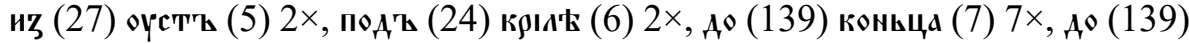

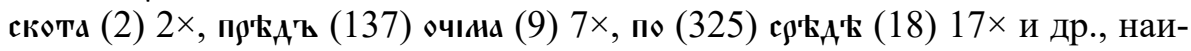
большее значение меры - 13,274, ${ }^{14}$ наименьшее - 5,140;

СУЩЕСТВИТЕЛЬНОЕ + ПРИТЯЖАТЕЛЬНОЕ МЕСТОИМЕНИЕ (49 -

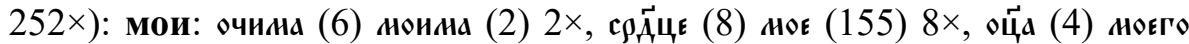
(113) $3 \times$ и др., нашь: гөъхтъ (26) нашихъ (20) $5 \times$, Бжє (71) наш'ъ (67) $20 \times$,

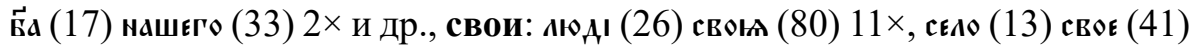

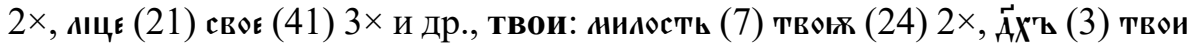
(72) $2 \times$, Братт (11) твои (72) $5 \times$, Аєсница (3) тво' (157) $3 \times$ и др., его: ГАав' (4) єго (729) $2 \times$, ноз' (5) кго (729) $2 \times$ и др., значения меры - 13,859-5,349;

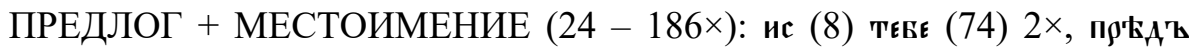

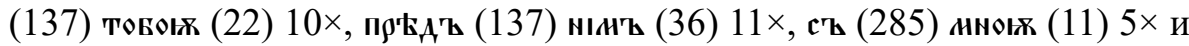
др., значения меры - 8,235-5,340;

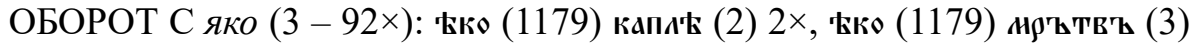
$2 \times$, кко (1179) влаг"ъ (33) 18×, значения меры - 6,241-5,367;

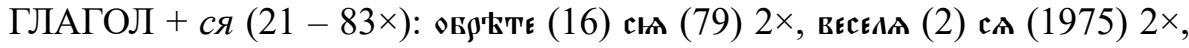

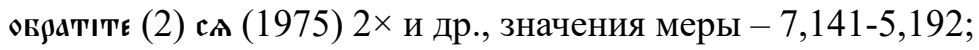

МЕСТОИМЕНИЕ + ЧАСТИЦА же $(2-65 \times)$ : онъ (83) жє (1185) (61×), т'Алъ (8) жє (1185) (4×), значения меры - 5,789-5,234;

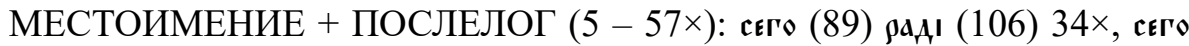
(89) ради (43) 9×, чєсо (20) ради (43) $2 \times$ и др., значения меры - 8,238-5,707;

12 Где 55 - количество сочетаний, 360 - количество случаев встречаемости в текстах коллекции.

${ }^{13}$ На первом месте приводятся биграммы, имеющие наибольшее статистическое значение.

${ }^{14}$ Выделены наибольшие для выборки значения меры. 


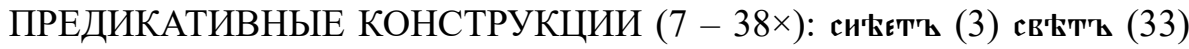
$2 \times$, тұы (68) єси (106) $5 \times$, єсм'ъ $(95)$ аъъ (117) $15 \times$ и др., значения меры 10,815-5,195;

СОЧЕТАНИЕ Господь Богъ $(3-31 \times)$ : га (6) Б̈а (17) $3 \times, \vec{\Gamma}$ (338) Б̈жє (75) $17 \times$, Г̆ъ (193) Б̈'ъ (139) $11 \times$, значения меры - 11,357-5,192;

ЧАСТИЦА не + ГЛАГОЛ (7 - 31×): мє (1283) в'ъзногхтт (2), мє (1283) ногжтқ (3), нє (1283) оттьвраты (5) и др., значения меры - 6,119-5,312;

ГЛАГОЛЬНО-ПРЕДЛОЖНЫЕ ФОРМЫ (11 - 30×): нападх (3) на (1053)

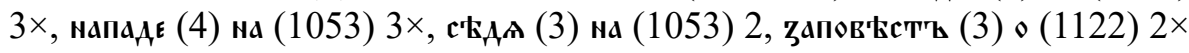
и др., значения меры - 6,404-5,403;

ГЛАГОЛ / ПРИЧАСТИЕ + МЕСТОИМЕНИЕ (9 - 24×): оүГотованов (2)

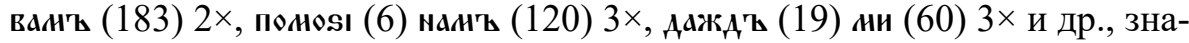
чения меры - 8,929-5,705;

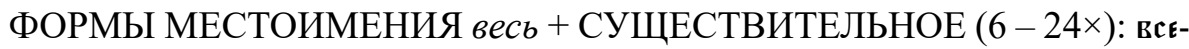

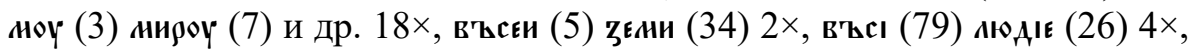
значения меры -13,052-7,440;

ПРИЛАГАТЕЛЬНОЕ / ПРИЧАСТИЕ + быти $(3-13 \times)$ : живи (2) БжАєТЕ

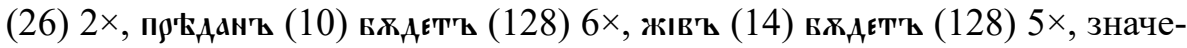
ния меры - 11,744-7,959;

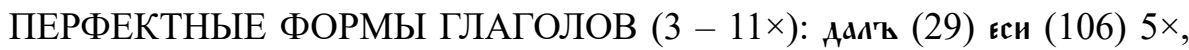

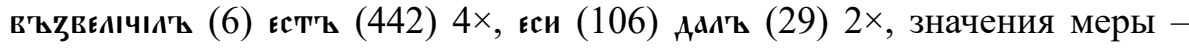
$7,180-5,858$;

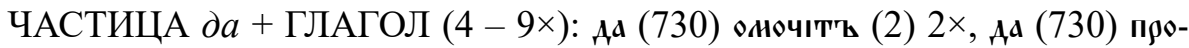
св'тттъ (3) 2× и др., значения меры - 6,933-5,196;

СУЩЕСТВИТЕЛЬНОЕ + ПРИЛАГАТЕЛЬНОЕ (3 - 7×): ९АЕи (6) нєАОстоини (2) $2 \times$, Аьнєсьнии (2) Аєнь (38) $2 \times$, вЊЧьн'Ы (10) Б̈Жє (71) $3 \times$, ЗНачения меры - 13,859-5,558;

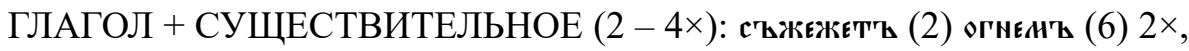

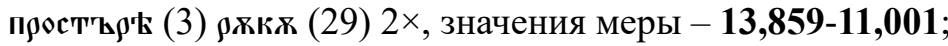

СОЧЕТАНИЕ другъ друга $(1-4 \times)$ : Арогъ (8) дроүга (13) 4×, значение меры - 11,744;

СОЧЕТАНИЕ свтотъ лица $(1-3 \times)$ : св'Ттъ (33) лица (19) $3 \times$, значение меры - 8,737 и нек. др. 


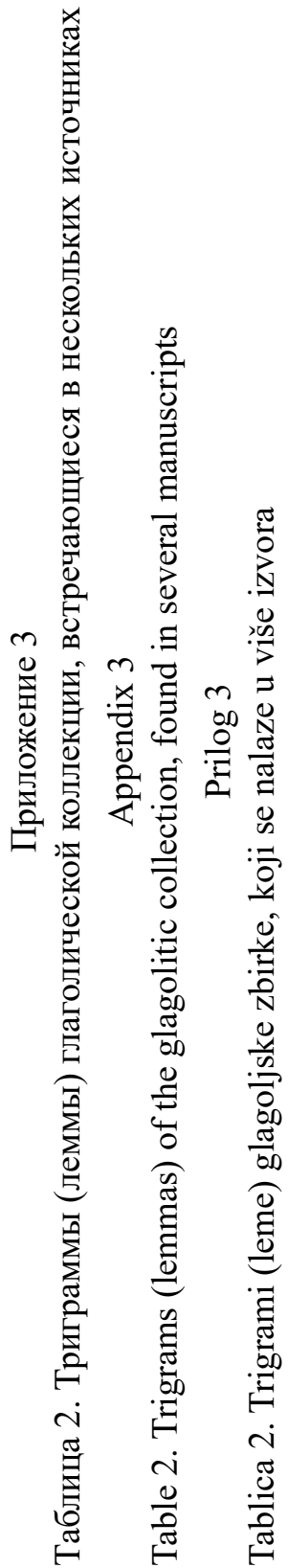

\begin{tabular}{|c|c|c|c|c|c|c|c|c|}
\hline 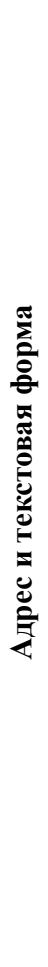 & 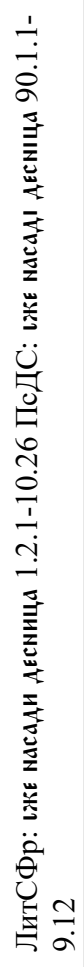 & 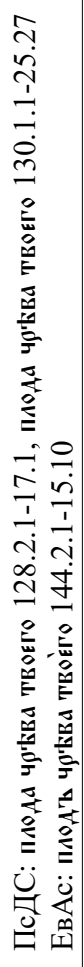 & 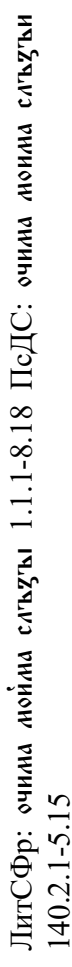 & 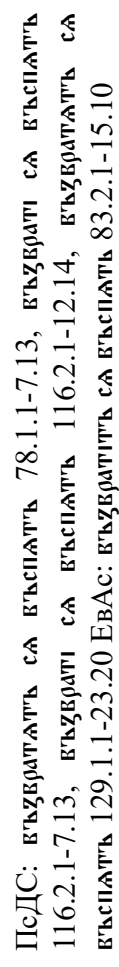 & 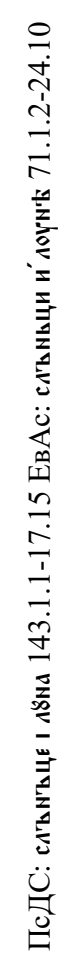 & 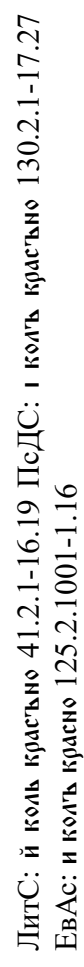 & 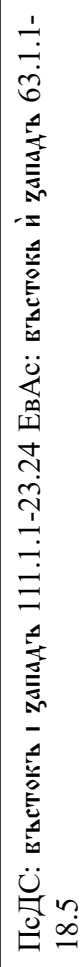 & 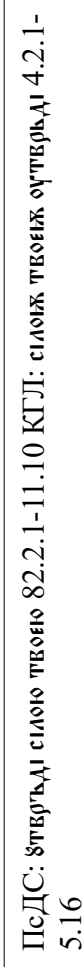 \\
\hline$\Sigma$ & $\begin{array}{l}\text { त్ } \\
0 \\
0 \\
0 \\
0 \\
1\end{array}$ & 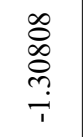 & 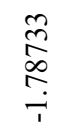 & $\begin{array}{l}n \\
\cdots \\
\stackrel{n}{i} \\
i\end{array}$ & $\begin{array}{l}\stackrel{8}{0} \\
\frac{1}{\hat{\sigma}} \\
\text { ণ }\end{array}$ & $\frac{\stackrel{\sim}{\forall}}{\underset{\sigma}{+}}$ & $\begin{array}{l}\stackrel{-}{\widetilde{N}} \\
\stackrel{\sigma}{+} \\
\stackrel{\sim}{r}\end{array}$ & 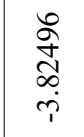 \\
\hline 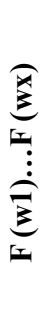 & 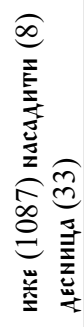 & 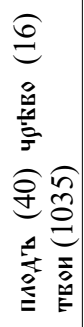 & 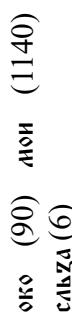 & 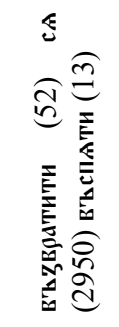 & 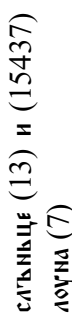 & 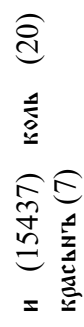 & 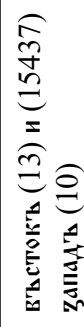 & 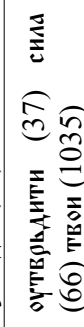 \\
\hline[ & $N$ & $c$ & $N$ & in & $N$ & $m$ & $N$ & 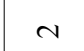 \\
\hline$\frac{\text { oin }}{\zeta}$ & $R$ & ஓे & $=$ & 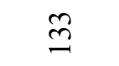 & 는 & $\simeq$ & $\widetilde{N}$ & $\mathrm{~N}$ \\
\hline$\frac{01}{2}$ & - & $N$ & $m$ & $\nabla$ & n & 6 & $r$ & $\alpha$ \\
\hline
\end{tabular}




\begin{tabular}{|c|c|c|c|c|c|c|c|c|}
\hline 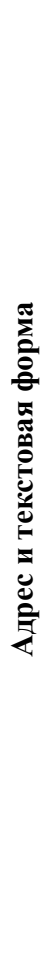 & 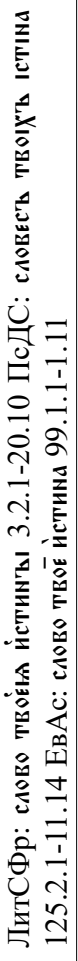 & 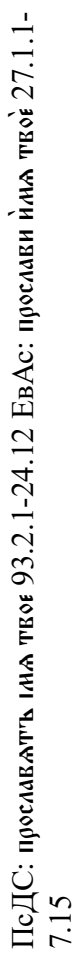 & 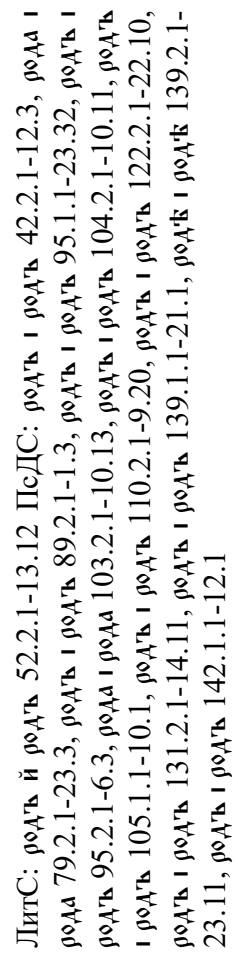 & 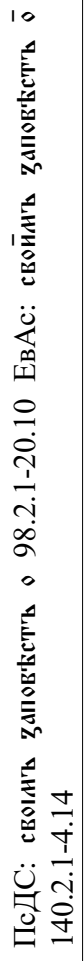 & 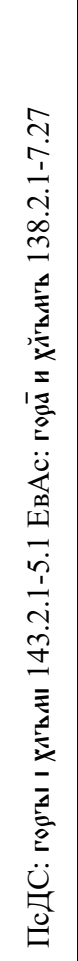 & 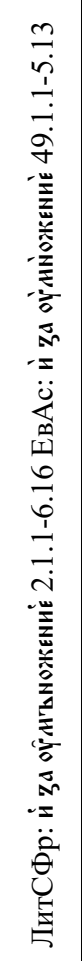 & 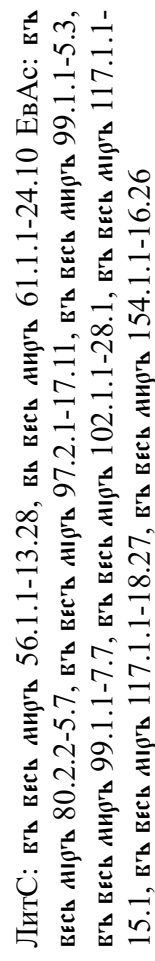 & 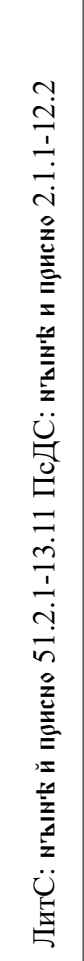 \\
\hline$\Sigma$ & 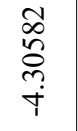 & 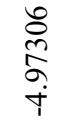 & $\begin{array}{l}\hat{\infty} \\
\infty \\
\hat{N} \\
\hat{n} \\
i\end{array}$ & $\begin{array}{l}\stackrel{0}{0} \\
\text { J̃ } \\
\stackrel{2}{1} \\
i\end{array}$ & $\begin{array}{l}\overline{8} \\
8 \\
\stackrel{2}{\circ} \\
\text { ip }\end{array}$ & $\begin{array}{l}\text { } \\
\text { } \\
\text { } \\
\stackrel{1}{i}\end{array}$ & 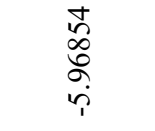 & $\begin{array}{l}\stackrel{n}{R} \\
\hat{\sigma} \\
0 \\
\dot{0}\end{array}$ \\
\hline 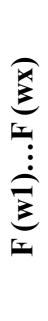 & 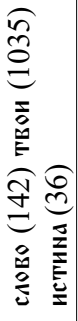 & 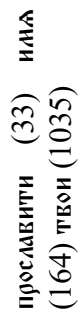 & 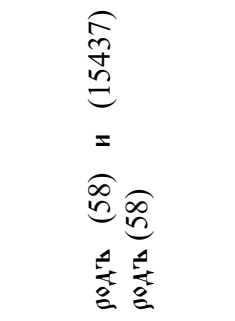 & 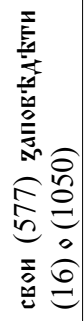 & 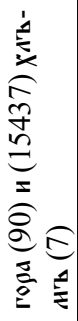 & 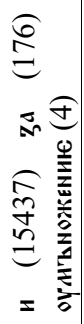 & 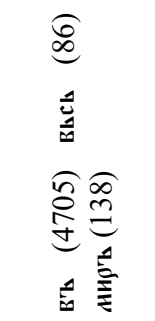 & 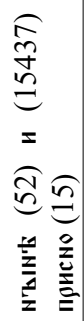 \\
\hline[ & $m$ & $\sim$ & - & $N$ & $\sim$ & $\sim$ & $=$ & $\sim$ \\
\hline$\frac{\text { oin }}{\zeta}$ & 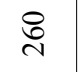 & $\stackrel{\widehat{n}}{\text { n }}$ & $\stackrel{\mathscr{n}}{n}$ & 우 & $\begin{array}{l}\infty \\
\stackrel{+}{+}\end{array}$ & $\stackrel{2}{\text { ว }}$ & $\stackrel{\leftrightarrow}{\forall}$ & $\mathcal{F}$ \\
\hline$\stackrel{\text { eir }}{\zeta}$ & $a$ & 으 & $=$ & $\simeq$ & $\stackrel{m}{-}$ & \pm & - & $\because$ \\
\hline
\end{tabular}




\begin{tabular}{|c|c|c|c|c|c|c|c|c|}
\hline 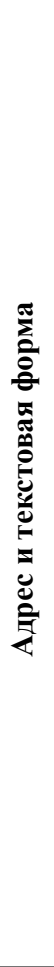 & 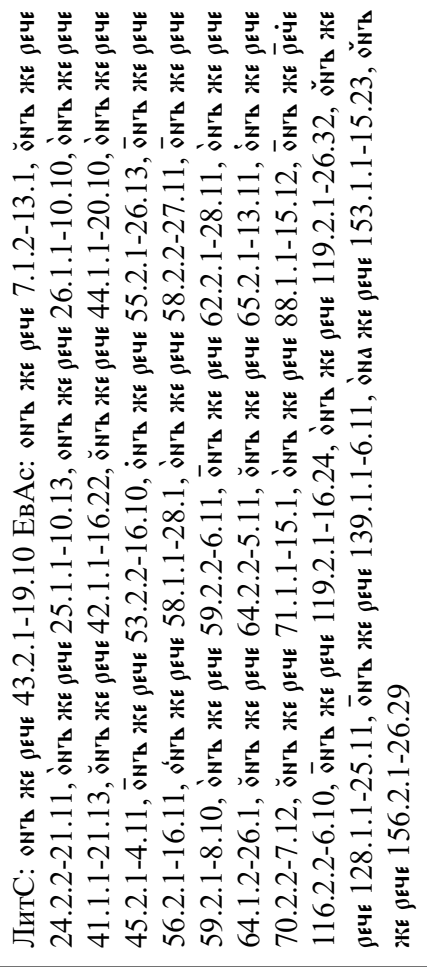 & 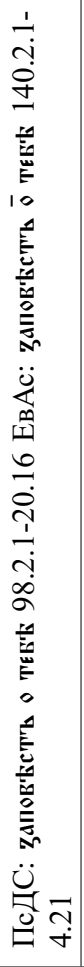 & 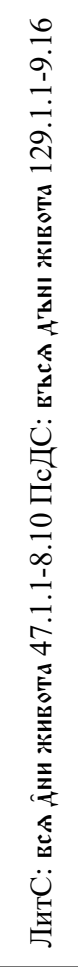 & 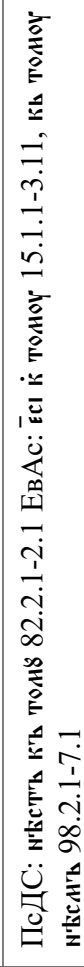 & 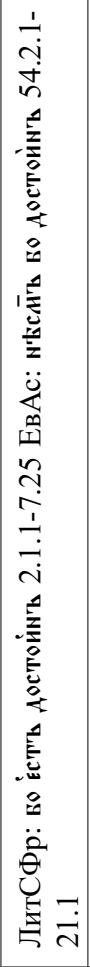 & 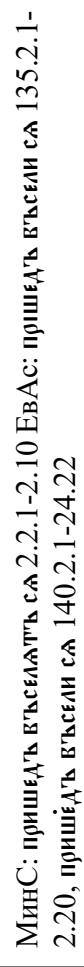 & 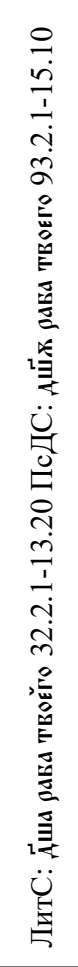 & 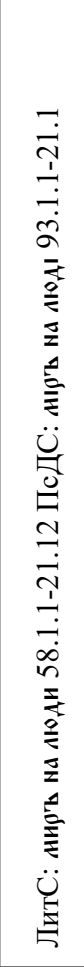 \\
\hline $\bar{\Sigma}$ & $\begin{array}{l}n \\
\tilde{b} \\
\infty \\
0 \\
0 \\
1\end{array}$ & 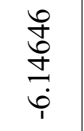 & 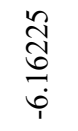 & $\frac{n}{\frac{n}{2}}$ & 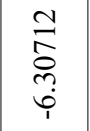 & 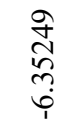 & \begin{tabular}{l}
$n$ \\
$\tilde{n}$ \\
\multirow{2}{*}{} \\
$\stackrel{0}{0}$
\end{tabular} & $\begin{array}{l}\infty \\
n \\
0 \\
0 \\
+ \\
+ \\
i\end{array}$ \\
\hline 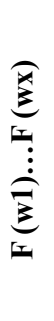 & 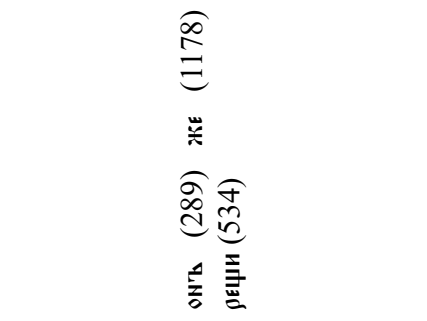 & 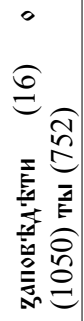 & 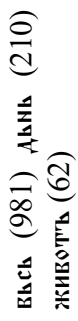 & 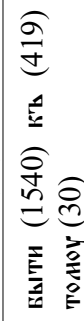 & 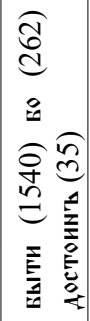 & 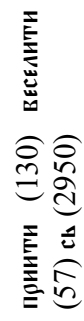 & 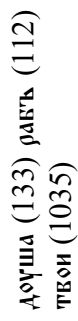 & 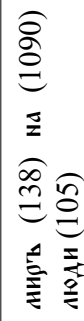 \\
\hline 工工 & m & $\sim$ & $N$ & $m$ & $N$ & $m$ & $N$ & $\sim$ \\
\hline$\frac{\text { oin }}{\zeta}$ & 寸 & $\stackrel{n}{f}$ & \% & f & $\stackrel{\infty}{+}$ & + & gे & 字 \\
\hline$\frac{\text { oin }}{2}$ & $\simeq$ & - & - & $\widetilde{N}$ & $\vec{\sim}$ & $\mathrm{N}$ & $\sim$ & $\sim$ \\
\hline
\end{tabular}




\begin{tabular}{|c|c|c|c|c|c|c|c|}
\hline 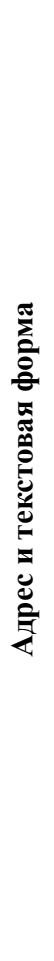 & 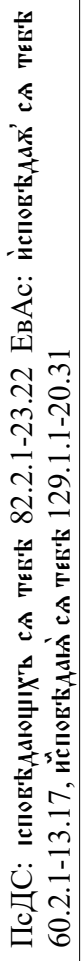 & 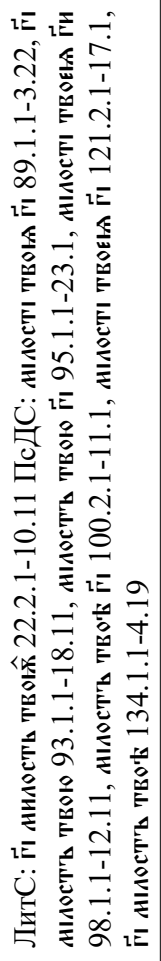 & 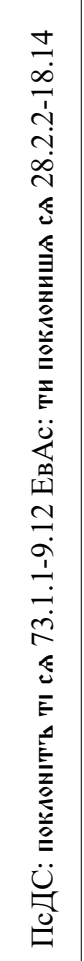 & 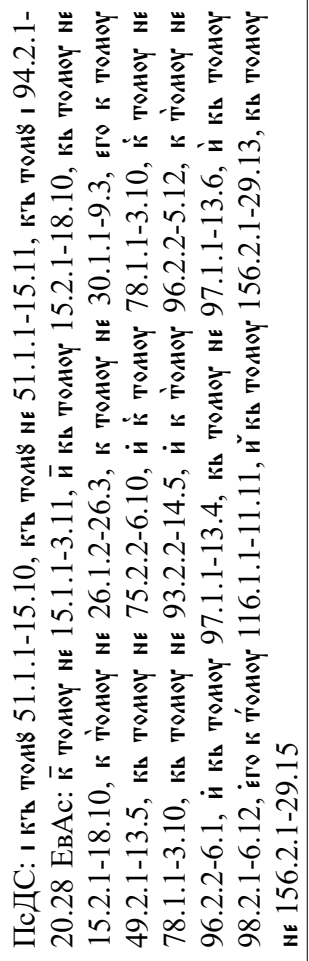 & 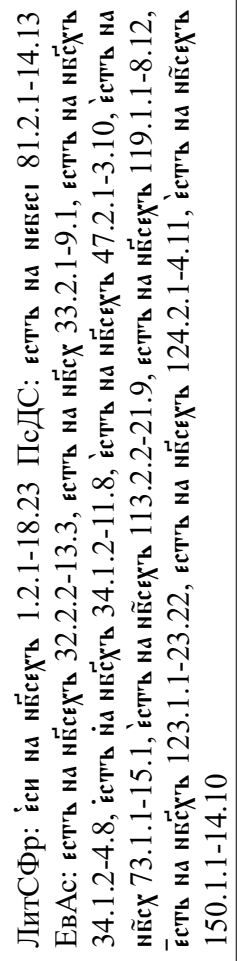 & 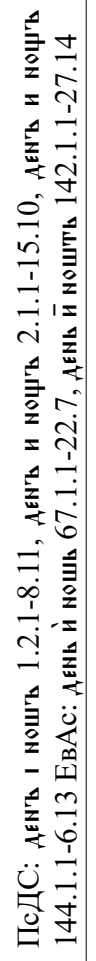 & 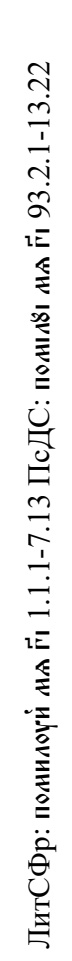 \\
\hline $\bar{\Sigma}$ & $\begin{array}{l}\infty \\
\hat{\sigma} \\
\widehat{0} \\
\dot{0} \\
1\end{array}$ & 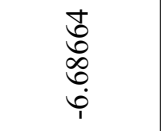 & $\begin{array}{l}\infty \\
0 \\
\Uparrow \\
\sigma \\
\dot{0} \\
i\end{array}$ & $\begin{array}{l}\infty \\
\\
\hat{\sigma} \\
\stackrel{0}{0}\end{array}$ & 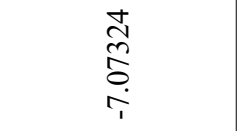 & $\begin{array}{l}\bar{\sigma} \\
\text { Tे }\end{array}$ & $\begin{array}{l}\infty \\
\infty \\
\infty \\
\stackrel{\sim}{n} \\
\stackrel{\pi}{1}\end{array}$ \\
\hline 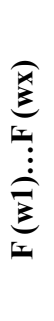 & 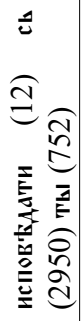 & 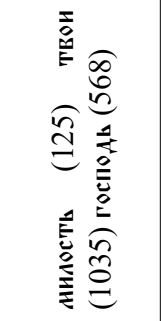 & 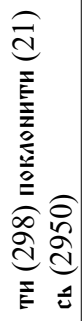 & 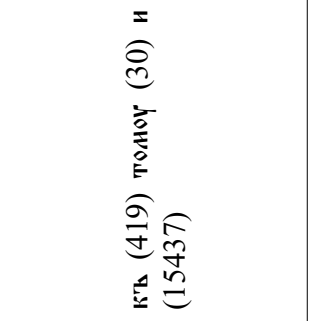 & 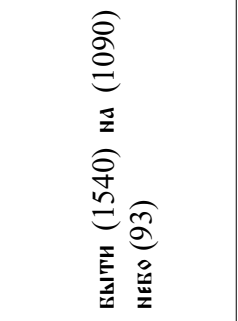 & 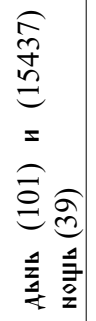 & 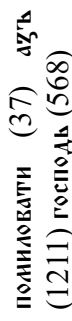 \\
\hline I & $n$ & $\infty$ & $N$ & $\vec{\sim}$ & - & in & $N$ \\
\hline$\frac{\text { oiv }}{\zeta}$ & $\frac{m}{n}$ & $\bar{n}$ & $\bar{n}$ & $\bar{n}$ & 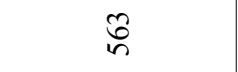 & $n$ & $\frac{d}{n}$ \\
\hline oi & $\sqrt{2}$ & $\sim$ & $\sim$ & $\sim$ & $\sim$ & $n$ & $\bar{m}$ \\
\hline
\end{tabular}




\begin{tabular}{|c|c|c|c|c|c|c|c|c|c|c|c|c|}
\hline 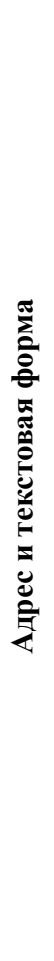 & 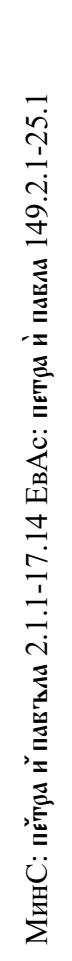 & 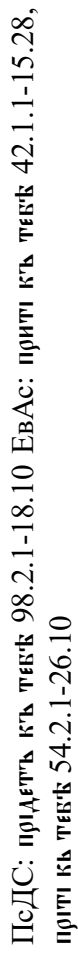 & 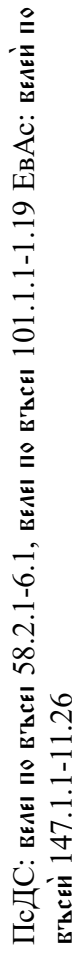 & 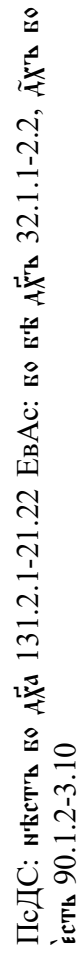 & 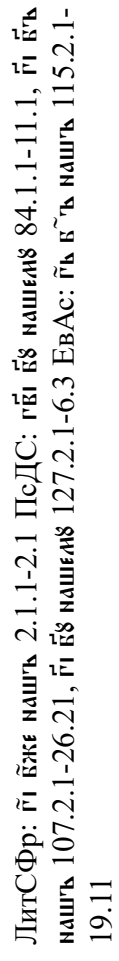 & 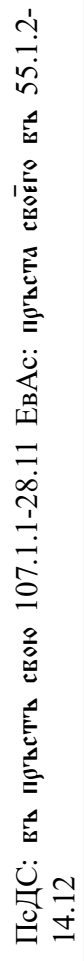 & 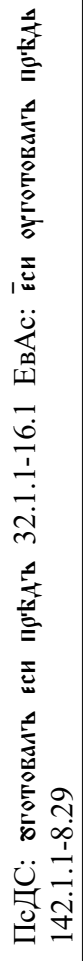 & 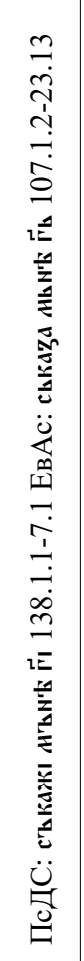 & 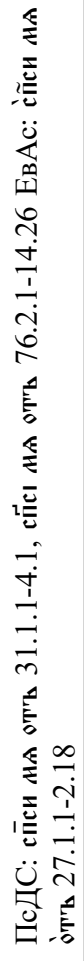 & 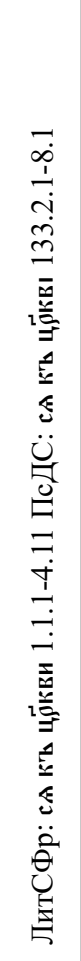 & 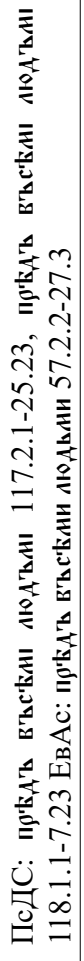 & 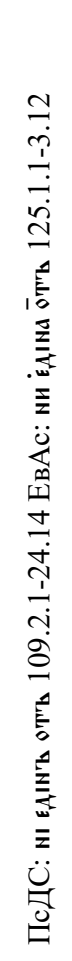 \\
\hline $\bar{\Sigma}$ & $\begin{array}{l}\bar{\delta} \\
\text { } \\
\\
\end{array}$ & 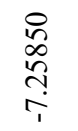 & $\frac{\pi}{n}$ & 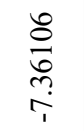 & 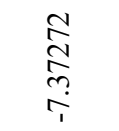 & $\begin{array}{l}n \\
\stackrel{n}{n} \\
\infty \\
n \\
r\end{array}$ & 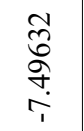 & 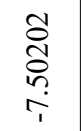 & 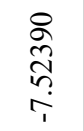 & 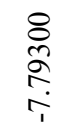 & 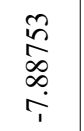 & $\frac{\infty}{n}$ \\
\hline 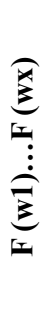 & 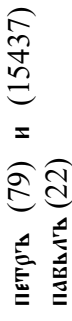 & 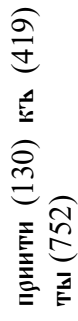 & 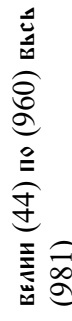 & 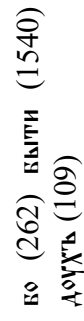 & 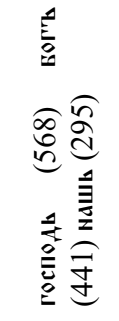 & 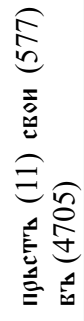 & 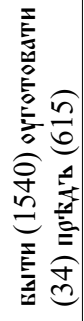 & 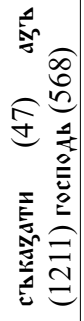 & 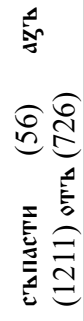 & 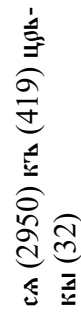 & 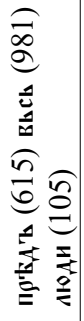 & 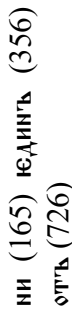 \\
\hline II & $N$ & $m$ & $m$ & $n$ & in & $\sim$ & $N$ & $\sim$ & $m$ & $\sim$ & $m$ & $\sim$ \\
\hline ת. & $\begin{array}{l}\infty \\
\infty \\
n\end{array}$ & in & ถे & 8 & 8 & 8 & $\widehat{6}$ & ชె & $\widehat{6}$ & $\hat{\sigma}$ & $\infty$ & $\infty$ \\
\hline$\frac{\text { oi }}{\zeta}$ & N & $\stackrel{m}{m}$ & m & $\stackrel{m}{m}$ & re & $\hat{n}$ & m & ले & q & $\bar{\sigma}$ & $\underset{f}{\mathcal{F}}$ & $\mathscr{f}$ \\
\hline
\end{tabular}




\begin{tabular}{|c|c|c|c|c|c|c|c|}
\hline 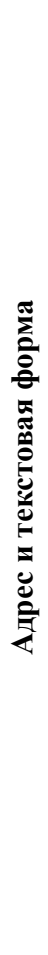 & 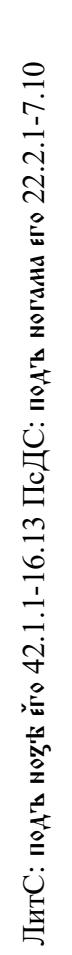 & 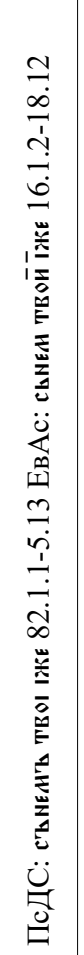 & 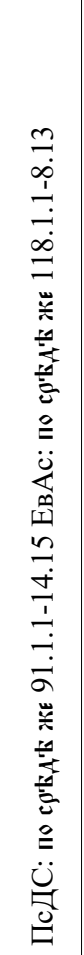 & 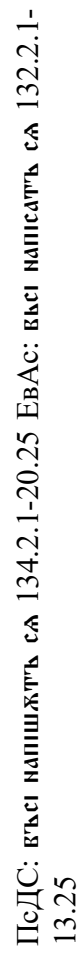 & 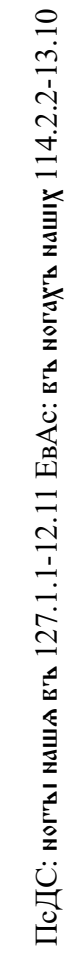 & 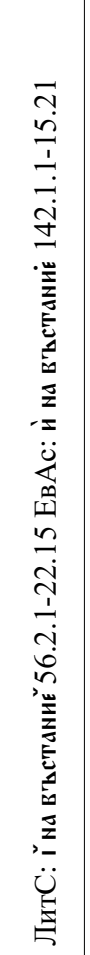 & 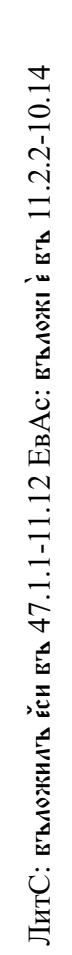 \\
\hline$\Sigma$ & 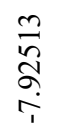 & $\frac{\infty}{\stackrel{\sigma}{\sigma}}$ & 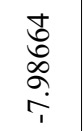 & 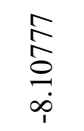 & 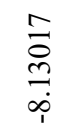 & 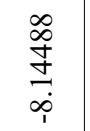 & 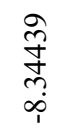 \\
\hline 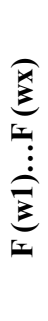 & 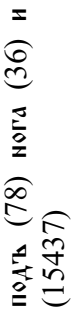 & 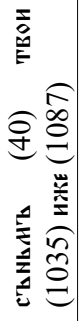 & 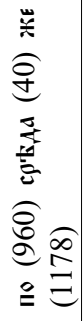 & 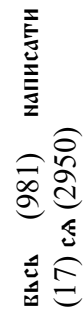 & 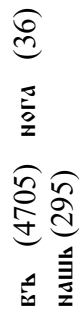 & 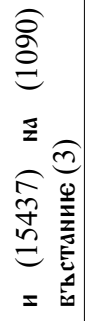 & 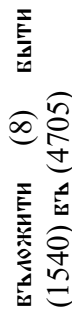 \\
\hline L & $N$ & $N$ & $N$ & $N$ & $N$ & $N$ & $\sim$ \\
\hline$\frac{\theta^{N}}{\zeta}$ & જิ & $\stackrel{n}{?}$ & $\hat{\circ}$ & $\stackrel{\infty}{N}$ & $\stackrel{N}{\sim}$ & $\approx$ & $\hat{\sigma}$ \\
\hline$\frac{01^{-1}}{5}$ & 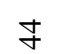 & $\stackrel{n}{\sigma}$ & fo & チ & $\stackrel{\infty}{+}$ & $\stackrel{q}{q}$ & in \\
\hline
\end{tabular}


S a ž e t a k

\section{Viktor A. Baranov \\ O PITANJU PRIMJENE STATISTIČKIH METODA U PRONALAŽENJU KOLOKACIJA I KOLIGACIJA U NAJSTARIJIM SLAVENSKIM TEKSTOVIMA (NA MATERIJALU GLAGOLJSKIH RUKOPISA KORPUSA »MANUSKRIPT«)}

Rad je posvećen pitanjima metodologije pretraživanja i procjene stabilnosti ustaljenih kolokacija u zbirci glagoljskih tekstova povijesnog korpusa Manuskript: slavjanskoe pis'mennoe nasledie (Manuskript: slavensko pismeno nasljeđe - manuscripts.ru). Prikazane su mogućnosti modula n-gram za ekstrakciju kolokacija - koje se sastoje od riječi i njihovih oblika ili lema - s različitim brojem komponenata i različitom učestalošću. Analiziraju se bigrami i trigrami izdvojeni pomoću statističke mjere uzajamne obavijesti (eng. Mutual Information - akr. MI), koji se pojavljuju istodobno u nekoliko rukopisa ove zbirke.

Posebna se pozornost posvećuje n-gramima s visokom statističkom vrijednošću mjere MI. U skladu s obilježjima mjere, najveću vrijednost u zbirci imaju rijetke kombinacije. Analiza takvih rijetkih bigrama na temelju oblika riječi omogućila je identificiranje koherentnih gramatičkih konstrukcija - koligacija. Pokazano je da su trigrami koji se sastoje od tekstualnih oblika, ne samo gramatičke, već i semantičke cjeline - kolokacije. Bigrami s komponentama-lemama su raznoliki - prijedložno-padežne kolokacije s imenicama i povratno-posvojnim zamjenicama te ostale atributivne konstrukcije, glagolsko-imeničke odnosne konstrukcije itd. Pomoću analize ovih skupina pronađene su kako koligacije, tako i kolokacije. Najproduktivniji rezultat bilo je izdvajanje trigrama na temelju lema: većina prvih nekoliko desetaka kombinacija koje imaju maksimalnu vrijednost u skladu sa statističkom mjerom uzajamne obavijesti - gramatičke su i semantičke cjeline ili njihovi dijelovi.

Donosi se zaključak o učinkovitosti primjene statističkih metoda za ekstrakciju kolokacija i koligacija iz korpusa srednjovjekovnih slavenskih rukopisa. Navedeno je da se za složeno rješenje postavljenog zadatka trebaju koristiti različite vrste n-grama - dvokomponentne i trokomponentne, utemeljene na tekstualnim oblicima i lemama, sa slobodnim i fiksnim redoslijedom komponenata. Prisutnost gramatički i semantički cjelovitih kolokacija koje se ponavljaju u različitim rukopisima omogućuje nam zaključak o nadtekstnoj prirodi takvih kolokacija.

Ključne riječi: tekstualni korpus »Manuskript«, manuscripts.ru, glagoljski rukopis, jezična statistika, modul n-gram, kolokacija, koligacija 


\section{Sum mary}

Viktor A. Baranov

\section{ON THE QUESTION OF THE APPLICATION OF STATISTICAL METHODS TO SEARCH FOR COLLOCATIONS AND COLLIGATIONS IN OLD SLAVONIC TEXTS (IN GLAGOLITIC MANUSCRIPTS FROM THE CORPUS $»$ MANUSCRIPT $«)$}

The paper deals with the questions concerning the methodology used to search for fixed collocations in the collection of Glagolitic texts in the historical corpus Manuscript: Slavic written heritage (manuscripts.ru) and to evaluate their stability. It demonstrates the possibilities of the n-gram module to extract collocations, consisting of words and their textual forms or lemmas, with different numbers of components and different frequency of occurrence. Analyzed are digrams and trigrams extracted using the statistical measure of Mutual Information (acr. MI) that occur simultaneously in several manuscripts from the collection.

Particular attention is given to n-grams with high statistical MI values. In accordance with the specifics of the measure, the greatest values belong to the collocations that are rare in the collection. The analysis of such digrams based on the word forms has enabled an identification of coherent grammatical structures - colligations. Trigrams consisting of textual forms are shown to be not only grammatical, but also semantic units - collocations. Digrams with components-lemmas have different forms: preposition-noun collocations, preposition-possessive pronoun collocations and other attributive constructions, relative verb-noun constructions, etc. The analysis of these groups identified both colligations and collocations. Extraction of trigrams on the basis of lemmas was the most productive - the greatest part of the first few dozens of collocations with a maximum MI value are grammatical and semantic units or their parts. A conclusion is made about the efficiency of application of statistical methods for the extraction of collocations and colligations from the corpora comprising medieval Slavonic manuscripts. A complex solution of the given problem requires the use of different types of n-grams - two-components and triple-components, based on textual forms and lemmas, with free and fixed component order. The presence of grammatical and semantic units repeated in various manuscripts leads to a conclusion about the supra-textual nature of such collocations.

Keywords: textual corpus »Manuscript, manuscripts.ru, Glagolitic manuscript, linguistic statistics, n-gram module, collocation, colligation

Viktor A. Baranov

Department of Linguistics

Izhevsk State Technical University after M.T. Kalashnikov

Izhevsk (Russia)

victor.a.baranov@gmail.com 